$12-4-2013$

\title{
Financial Restatements, Litigation, and Implied Cost of Equity
}

\author{
Katsiaryna Salavei Bardos
}

Dev Mishra

Follow this and additional works at: https://digitalcommons.fairfield.edu/business-facultypubs (C) 2013 Taylor \& Francis

The post-print version has been archived here with permission from the copyright holder.

\section{Peer Reviewed}

\section{Published Citation}

Bardos, Katsiaryna Salavei, and Dev Mishra. "Financial restatements, litigation and implied cost of equity." Applied Financial Economics 24, no. 1 (2014): 51-71. https://doi.org/10.1080/09603107.2013.864033

This item has been accepted for inclusion in DigitalCommons@Fairfield by an authorized administrator of DigitalCommons@Fairfield. It is brought to you by DigitalCommons@Fairfield with permission from the rightsholder(s) and is protected by copyright and/or related rights. You are free to use this item in any way that is permitted by the copyright and related rights legislation that applies to your use. For other uses, you need to obtain permission from the rights-holder(s) directly, unless additional rights are indicated by a Creative Commons license in the record and/or on the work itself. For more information, please contact digitalcommons@fairfield.edu. 


\title{
Financial Restatements, Litigation, and Implied Cost of Equity
}

\author{
Katsiaryna Salavei Bardos \\ Dolan School of Business, Fairfield University \\ kbardos@fairfield.edu \\ Dev Mishra \\ Edwards School of Business, University of Saskatchewan \\ mishra@edwards.usask.ca
}

Applied Financial Economics 24 (1), pages 51-71, 2014

\begin{abstract}
We reexamine the effect of financial restatements on the cost of equity vis-a-vis litigation risk. Specifically, we study the effect of litigation on post-restatement financing costs and whether market anticipates litigation before restatement announcement as evident from its effect on financing costs. In a sample of 91 restatements, while we find that the cost of equity increases subsequent to a financial restatement for all restating firms, the increase is substantially greater for firms facing litigation as a result of the restatement. We also find that investors do not adjust for the cost of equity prior to the announcement of a financial restatement for firms facing post-restatement litigation. Overall, our findings suggest that most of the increase in the cost of equity after restatement is concentrated in sued sub-sample and that the cost of equity is an important channel through, which litigation associated with financial restatement is priced. The economic effect of post-restatement litigation is approximately 259 basis points increase in the firm's cost of equity.
\end{abstract}

Keywords: Cost of Equity, Litigation, Financial Restatements, Earnings Forecasts, Analyst Forecasts

JEL Classification: G14, G12, K22, M41 


\section{Introduction}

Due largely to their negative valuation effect, financial restatements attracted significant attention from policy-makers and helped motivate various regulations, including some provisions of the Sarbanes Oxley Act of 2002 (Agrawal and Chadha, 2005). A sizeable stream of literature has sought to understand the economic effects of financial restatements by publicly traded corporations (Palmrose et al., 2004; Bardos and Zaiats, 2012). Negative valuation effect of restatement announcement may be attributed to: i) the adjustment down of expected future cash flows and/or ii) the upward adjustment of the cost of capital. In a sample of restatements, Hribar and Jenkins (2004) find evidence supporting a significant valuation effect through both of these channels. In particular, first, they find that analysts revise forecasts downward subsequent to restatements. Second, they find that the cost of equity increases following restatements, and that the increase in the cost of equity is larger for auditor initiated restatements and highly levered firms. Consistent with the findings of Hribar and Jenkins, Graham et al., (2008) find that restatements increase the cost of debt and have adverse impact on loan contracting. More specifically, they find that loans initiated after restatement have significantly higher spreads, shorter maturities, higher likelihood of being secured, and more covenant restrictions than loans initiated before restatement. Gleason et al., 2005 and Wilson (2008) find that investors temporarily loose confidence in the credibility of subsequent financial reports of restating firms.

Prior literature cites several potential reasons why restatements may trigger decreases in expected future earnings and increases in the cost of capital resulting in the loss of firm value. First, restatements may reveal that previously reported earnings were overstated, which would result in downward revision of expected future earnings. Empirical evidence supports this reasoning (Hribar and Jenkins, 2004; Palmrose et al., 2004). Second, loss of management credibility may indicate suboptimal investment and operation policies, and thus may lead to an increase in the costs of internal monitoring, costly management changes, and increased regulatory scrutiny. Accordingly, Burks (2010), Desai et al. (2006) and Agrawal and Cooper (2007) find high turnover among top management (e.g., CEOs and CFOs) and poor job prospects subsequent to restatements. Moreover, top management of firms named in SEC enforcement actions -- many of which result in a restatement -- face harsh legal and regulatory sanctions and suffer substantial losses (Karpoff, et al. 2007a, 2007b). Third, restatements can 
increase uncertainty about the overall quality of financial statements and thus increase information risk of the firm. Consistent with this prediction, Kravet and Shevlin (2010) find an increase in the pricing of earnings quality subsequent to restatements. Bardos (2011) finds that liquidity decreases for several years after restatement.

The class action lawsuit following a restatement is potentially another important factor that triggers a decrease in expected future earnings and an increase in the cost of capital. Literature points that restatements are likely to attract litigation. Jones and Weingram (1997) analyze five factors that influence the likelihood of being subject to class action (Rule 10b-5) (restatements, insider trading, seasoned equity offerings, SEC enforcement actions, and negative press releases) ${ }^{1}$ and find that restatement increases litigation risk more than all other events. Bradley, Cline, and Lian (2010) also find that restatement increases the likelihood of litigation for a larger sample of class action lawsuits. Litigation is a costly event for the firm and imposes large direct and indirect costs to defendant firms (Gande and Lewis, 2007). Palmrose and Scholz (2004) find that $37 \%$ of restating firms are sued as a result of a restatement. They also show that sued restating firms experience significantly higher negative market reaction (-22\%) to the restatement announcement compared to non-sued restating firms (-4\%). Similarly, Bardos et al., (2013) find that litigation risk is an important determinant of market reaction to restatements, which accounts for as much as $50 \%$ of stock price drop. However, the literature is silent on the effect of litigation on post-restatement financing costs. Apart from this, no prior work has examined whether anticipation of litigation affects the cost of capital before restatement announcement. In this paper, we fill this void in the literature by studying the link between litigation-triggering financial restatements and the firm's cost of equity.

We address this question by empirically examining the effect of litigation triggering restatements on the cost of equity and expected future cash flows compared to restatements that are not followed by litigation. It is plausible that the increase in the cost of equity after restatements documented by Hribar and Jenkins (2004) is entirely driven by litigation triggering restatements and cannot be generalized to the entire sample of all restating firms, therefore

1 Securities class action lawsuits filed under Rule 10b-5 allege material flaws pertaining to firms' disclosure. Allegedly, firms' misstatements cause inflation in the stock price during the class action period. Most of these lawsuits are filed on behalf of shareholders who bought the stock during the period of inflated stock prices and are entitled to compensation. 
weakening their conclusion that "perceptions about earnings quality affects a firm's cost of capital" (page 339). It does not rule out the possibility that the decrease in earnings quality in the absence of potential litigation (e.g. due to fraud) does not affect systematic risk.

We estimate the cost of equity for three months prior to a restatement and three months after a restatement using four models of implied cost of equity: Easton (2004), Ohlson and Juettner-Nauroth (2005), Gebhardt et al., (2001), and Claus and Thomas (2001). ${ }^{2}$ Implied cost of capital methodology allows us to separate cash flow and cost of capital effects. We use analyst forecasts revised after the announcement of both restatement and litigation to control for the cash flow effect when estimating after-event cost of equity. Griffin (2003) shows that financial analysts revise forecasts in the month of corrective disclosure, such as a restatement, and Barniv and Cao (2008) find that the market relies more on analyst forecasts after restatement announcement. There should be no change in the cost of equity if litigation costs are fully priced through the cash flow effect. In that case, much larger stock price decline associated with litigation triggering restatements can be fully attributed to the cash flow effect. At the same time, Kim and Shi (2011) find that disclosure of negative earnings forecasts by management results in higher cost of capital in the month after the disclosure, suggesting that negative financial information reflected in restatements also affects systematic risk.

We find that the cost of equity increases after restatement for all firms. However, the increase in the cost of equity is substantially greater for firms that are sued as a result of a restatement. In univariate tests, while we find that sued restating firms have greater decline in expected cash flows than non-sued restating firms, the cost of equity increases by 350 basis points after restatement for the sued sub-sample (35 firms) and by only 40 basis points for the non-sued sub-sample (56 firms). Our results suggest that a tort reform might influence market reaction to litigation triggering events, such as restatements, consistent with Li (2009), who shows that relaxing the legal liability can result in more information flow to the public.

A potential concern with the interpretation of our results is that restatements that prompt a larger share price decline influence both the equity cost of capital and the likelihood of

\footnotetext{
2 We use three month window because this gives us the largest sample size among the windows used in prior studies, such as Hribar and Jenkins (2004). However, we do later perform robustness tests for other windows.
} 
litigation. To address this endogeneity concern, we perform an analysis of the cost of capital for a sub-sample of sued and non-sued restating firms matched on restatement announcement return. We are able to create 24 matched pair of sued and non-sued firms (total 48 firms), all result holds for this sub-sample.

In cross-sectional tests, we continue to find a significant and positive cost of equity effect of post-restatement litigation after controlling for other determinants of the cost of equity. Economically, the incremental effect of post-restatement litigation is an increase of approximately 259 basis points in the firm's cost of equity. Accordingly, we also find that investors do not adjust the risk premium for firms that are sued as a result of a restatement prior to restatement announcement. Overall, our findings suggest that the cost of equity is an important channel through which restatement-associated litigation is priced. Our results support theoretical work of Easley and O'Hara (2004) and Lambert et al. (2007) who show that information risk is non-diversifiable.

We contribute to the literature in corporate reporting, cost of capital, and corporate finance in several ways. First, this is the first study that examines the effect of litigationtriggering restatements on the cost of equity. The existing literature largely assumes that restatements affect firm value through expected cash flows (e.g., Palmrose et al., 2004; GAO, 2002). Hribar and Jenkins (2004) implicitly assume that all restatements increase the cost of equity, regardless of whether or not a firm is sued as a result of a restatement. Our results show that most of the increase in the cost of equity is concentrated in litigation-triggering sub-sample. Second, the importance of the cost of capital as the key element used in evaluating a firm's strategic long-term investments makes learning the role of litigation-triggering restatements in the firm's financing costs important.

Third, our use of the cost of equity as the main test vehicle offers several other advantages. First, we closely relate and complement Hribar and Jenkins by examining cost of equity implications of litigation-triggering restatements, however, unlike Hribar and Jenkins we rely on the cost of equity estimates from four different models consistent with more recent literature (e.g., Hail and Leuz, 2006; Dhaliwal et al, 2006; Guedhami and Mishra, 2009). Our use of average of several discounted valuation models is superior and consistent with more recent literature (Hail and Leuz, 2006; Dhaliwal et al., 2006; El Ghoul et al., 2011) because the use of a single model is likely to lead to spurious results. For example, Dhaliwal et al. (p. 699) state that 
"there is considerable variation in the magnitude of the associations between the various implied cost of equity estimates and individual risk proxies, and there does not appear to be a consensus as to the superiority of any particular model in estimating the cost of equity." Second, the finance literature often uses valuation measures, such as Tobin's $Q$ or abnormal returns, to examine the effect of corporate events. Tobin's Q is also a proxy for firm growth and investment opportunity (e.g., see Géczy et al., 1997; Pham et al., 2007). Firms with higher potential growth and greater investment opportunities are expected to have higher market to book ratios. Therefore, a change in valuation measures, such as Tobin's $Q$, may simply reflect an expected change in the firm's growth rate instead of litigation risk. Our use of cost of equity rather than a valuation measure largely mitigates this issue.

Fourth, we also contribute to the literature that studies the effect of securities litigation. Litigation is a very costly event for shareholders (Gande and Lewis, 2007). Because restatements increase the likelihood of costly litigation, restating firms facing litigation after a restatement are likely to experience a larger loss in firm value at the announcement of a restatement. Consistent with this idea, Bardos et al., (2013) find that a one percent increase in litigation risk decreases cumulative abnormal stock return by $1.5 \%$ at the announcement of a restatement. A likely connection of litigation to corporate valuation is that the market may downward adjust expected cash flows after restatement, thus negatively affecting firm value. Another plausible effect of litigation on valuation which is often ignored in the literature is an upward adjustment in the cost of equity. We contribute to the literature by showing that the cost of capital is an important channel through which litigation associated with financial restatement affects firm value. Our models allow us to estimate the cost of equity by simultaneously controlling for the effect of litigation (if any) on the firm's expected cash flows.

Apart from the contributions to the literature discussed above, our findings are relevant for several groups of practitioners. In particular, stock analysts providing price recommendations may benefit from incorporating our results in their valuation models. Literature suggests that the quality of stock recommendations largely depends on the accuracy of the forecasts of expected earnings and earnings growth. For example, several studies, including Bradshaw (2004), Ertimur et al. (2007), Francis and Soffer (1997), and Loh and Mian (2006), find that more accurate forecasts are associated with more profitable recommendations. Accordingly, Bandyopadhyay et al. (1995) find analysts' price target forecasts largely depend on 
forecasted earnings. However, empirical evidence suggests that analysts are slow to react to financial restatements (Griffin, 2003). Importantly, for analysts providing price recommendations for restating firms, the lag in reactions may be caused primarily by their failure to properly adjust the cost of equity in the face of post-restatement litigation. Prior research has shown that firms that face high litigation risk are identifiable (Jones and Weingram, 1997; Francis et al., 1994; Gande and Lewis, 2007). Therefore, analysts and investors may estimate the likelihood of litigation using the models developed in these studies as a potential guide and adjust the cost of equity upwards for firms that face high litigation risk after restatement announcement.

Our findings may also interest investors and policy-makers who are trying to assess the full impact of restatements. For example, as stated earlier in this section, financial restatements have received significant attention from policy-makers and helped motivate various regulations (Agrawal and Chadha, 2005). Our findings may further bolster this interest from policy-makers in pin-pointing future regulations related to financial information reporting and restatements as well as tort reform.

The paper proceeds as follows. Section 2 discusses the data and the research design. Section 3 describes the results. Section 4 concludes.

\section{Data and Research Design}

Our sample consists of U.S. firms from three different sources. First, we start with 537 financial restatement announcements made by 496 U.S. Corporations from January 1, 1997 through June 30, 2002. We manually collected restatement dates and restatement characteristics from Lexis-Nexis and Factiva databases. We searched Lexis-Nexis and Factiva databases using key words "restatement," "restat," "revis," "adjust," "error," and "responding to guidance from the SEC" from January 1, 1997 through June 30, 2002. There are two advantages to using this period for our analysis. First, the GAO made a sample of restatements announced in this period publicly available, which allowed us to cross-check announcement dates and other restatement characteristics. Second, all restatements precede the Sarbanes-Oxley Act, which is, according to Li et al. (2008, pp. 111), " the most important legislation affecting corporate financial reporting enacted in the United States since the 1930s." Therefore, our results are free from the potential effect of this 
major regulatory change on the firm's cost of capital. Moreover, restatements after SOX became more technical in nature (Burks, 2010). ${ }^{3}$

We then merged this sample of restatements with the firms represented in Compustat North America and Thompson Institutional Brokers Earnings Services (I/B/E/S) for the event years, which left us with 345 restatements made by 326 firms. We selected the firms for which I/B/E/S contained information within +3/-3 months surrounding the event month, where event month is defined as the month containing the restatement announcement. Following the existing literature (e.g., Dhaliwal et al., 2006), we required that the I/B/E/S earnings history file contained: i) a positive mean earnings forecast for the first two years, ii) five-year mean growth rate in earnings or third year earnings forecast, ii) at least three analysts providing earnings forecasts for years 1 and 2, and iii) a statistics release date which preceded the forecast period end date. Furthermore, the following requirements had to be met: i) the I/B/E/S price history file had to contain a price for the corresponding statistics record period, ii) a positive book value per share had to be available in Compustat for the beginning of the fiscal year for which cost of equity is estimated, and iii) firms had to be covered in the Fama and French (1997) forty-eight industry classifications. The mean of forecasted five-year earnings growth rate, where available, and otherwise, the growth in mean forecasted earnings over the first three years constituted our proxy for the firm's long-term earnings growth. In the merged database, we included annual inflation measured by changes in the consumer price index recorded in the

\footnotetext{
${ }^{3}$ In arriving at 537 restatements, we imposed the following data filters to 918 restatements reported by GAO. First, we deleted 130 restatements that were the result of an adoption of new accounting rules. Second, we deleted 186 restatements that did not have necessary data for our analysis in the Center for Research in Security Prices (CRSP) and Compustat databases. Third, we deleted 25 restatements because we could not find necessary information about the restatement in Lexis-Nexis. Fourth, we deleted 20 restatements because, despite the announcement of a restatement, the firm did not restate financial statements. Fifth, we deleted 25 restatements for other reasons. We found five restatements that were not listed in GAO sample. Sixteen restatement announcements in the GAO sample are releases of new information regarding already announced restatements. This category also includes restatements that were not a result of a mistake or a misinterpretation of accounting rules (for example, restatements due to changes in the number of shares).
} 
month of June, annual constant maturity ten-year U.S. Treasury bond rate, and three-month U.S. Treasury bills rate. 4

We estimated cost of equity capital as described in section 2.1 below. We selected only those events for which we were able to estimate at least one valid cost of equity in the three month window preceding restatement announcement and one valid cost of equity during a three month window after restatement. Our final sample consists of 91 restatements made by 88 firms (see exhibit 1).

\subsection{Estimation of the Cost of Equity}

Unlike realized returns, a more direct measure of expected returns based on current prices, expected earnings per share, dividends, and book value per share, has gained some popularity since late 1990s, (e.g., Claus and Thomas, 2001; Gebhardt et al., 2001; Gode and Mohanram, 2003; Dhaliwal et al., 2005, 2006; Hail and Leuz, 2006; Guedhami and Mishra, 2009; among others). ${ }^{5}$ Many recent studies use more than one model to estimate the cost of equity capital (e.g., Dhaliwal et al., 2005, 2006; Botosan and Plumlee, 2005), while others, and especially initial studies, relied on cost of equity estimates of a single model (e.g., Claus and Thomas, 2001; Gebhardt et al., 2001; Francis et al., 2005).

We use four popular implied cost of capital models that built on the premises of accounting-based residual income valuation methods of Edwards and Bell (1961), Feltham and Ohlson (1995), and Ohlson (1995), and abnormal growth models of Ohlson and JuettnerNauroth (2005). These models are Easton (2004 ES), Ohlson and Juettner-Nauroth (2005 OJ), Gebhardt, Lee, and Swaminathan (2001 GLS), and Claus and Thomas (2001 CT). We follow Dhaliwal et al. (2006) and Hail and Leuz (2006), and use the average of the four different estimates of cost of capital to represent the implied cost of capital. We denote the cost of equity estimates from these models as $\mathrm{K}_{\mathrm{ES}}, \mathrm{K}_{\mathrm{OJ}}, \mathrm{K}_{\mathrm{GLS}}$ and $\mathrm{K}_{\mathrm{CT}}$, respectively. Our final cost of equity estimate " $\mathrm{K}$ " is the average of the cost of equity estimates of these four models. From these cost

\footnotetext{
${ }^{4}$ Treasury yields were extracted from the Federal Reserve St. Louis at http://research.stlouisfed.org/fred2/.

${ }^{5}$ While our purpose is not to debate the choice of an asset pricing model, it is worth pointing out that average realized returns are poor proxies for expected returns (Elton, 1999; Fama and French, 1997, 2004). Elton's (1999) presidential speech focused on the need for an alternative proxy for expected returns.
} 
of equity estimates, we calculate the firm's cost of equity premium by subtracting the yields on three-month U.S. Treasury Bills (RP3) and ten-year U.S. Treasury bonds (RP10). The use of RP10 is more common in the literature (Dhaliwal et al., 2006; Gode and Mohanram, 2003). A more detailed description of these methods and their implementation is provided in Appendix A.1, Dhaliwal et al. (2006) and Hail and Leuz (2006).

\subsection{Litigation}

Post-restatement firms may be sued either by shareholders through a class action lawsuit or by other market participants, such as pension funds and other institutional investors. We searched Lexis-Nexis and Stanford Law School Securities Class Action Clearinghouse for announcements of litigation after restatements. We retained the announcements that explicitly mentioned the restatement as a reason for the lawsuit. We find that $38.46 \%$ of our final sample was sued as a result of financial restatements. This is similar to other related studies: $38 \%$ in Palmrose and Scholz (2004) and 34\% Bardos et al. (2013).

Securities litigation is a costly event for the firm, with most of the cost resulting from a market rather than regulatory penalty (Gande and Lewis, 2007; Francis et al., 1994). For example, Griffin et al., (2004) find that firms named in federal securities class action lawsuits experience three-day excess returns of $-16.6 \%$ at the end of class action period (which is usually the date of restatement announcement for restating firms), and $-4.1 \%$ at the filing of the lawsuit.

Prior literature finds that firms that restate financial statements face a very high probability of litigation. For example, after controlling for stock market characteristics that influence litigation risk, Jones and Weingram (1997) find that restatement increases litigation risk more than insider trading, seasoned equity offerings, SEC enforcement actions, and negative press releases. Similarly, Griffin et al., (2004) find that stock price responses to news of securities litigation are more negative for class actions with accounting allegations versus nonaccounting allegations and Chalmers, Naiker and Navissi (2011) find that sued firms have poor earnings quality prior to litigation announcement. Johnson et al., (2007) find that restatements were insignificantly associated with the filing of a law suit prior to the enactment of the Private Securities Litigation Reform Act of 1995 (PSLRA), but are positively associated with the filing of law suits post-PSLRA. ${ }^{6}$ While a restatement increases litigation risk more than other important

\footnotetext{
${ }^{6}$ See also Geiger, Raghunandan and Rama (2006) and Lam and Mensah (2006).
} 
corporate events, not all restating firms are sued (Palmrose and Scholz, 2004; Bardos et al., 2013; and this study). However, prior research suggests that high litigation risk firms are identifiable (Jones and Weingram, 1997; Francis et al., 1994). Therefore, at the announcement of restatement, investors can assess the likelihood of litigation of restating firms. We hypothesize that firms that

were sued as a result of restatement will experience larger increases in the cost of equity than firms that did not get sued.

We also examine whether the market anticipates lawsuits and increases the risk premium for litigation-triggering restatements prior to restatement announcement. This is motivated by the findings in the prior literature that litigation is predictable. For example, Gande and Lewis (2007) show that investors partially anticipate shareholder class action lawsuits and capitalize part of these losses prior to the lawsuit filing date. They also find that high litigation risk firms have greater partial anticipation effects and smaller filing date effects. Griffin et al., (2004) find that the outcome of litigation is partially anticipated by the stock market and that abnormal returns at the end of the class action period are correlated with the outcome of the litigation. Jones and Weingram (1997) and Francis, et al., (1994) find that high litigation risk firms are identifiable ex-ante.

\subsection{Control Variables}

Our choice and specification of control variables shown to affect the cost of equity capital closely follow Dhaliwal et al. $(2005,2006)$. First, we use the loadings for the Fama-French (1993) three risk factors, namely, $\beta_{M K T}, \beta_{S M B}$ and $\beta_{H M L}$. We estimate these factors by regressing 24 to 60 months of monthly excess stock returns (over the risk-free rate) in the Fama-French threefactor model in a window of the prior sixty months ending in the December of the cost of equity estimation year. These loadings serve to control for three important firm-specific risk factors used in the implied cost of capital literature. i) $\beta_{M K T}$ controls for the effect of systematic risk often measured by the firm's beta and expected to load with a positive coefficient (Dhaliwal et al., 2006; Gode and Mohanram, 2003). ii) $\beta_{S M B}$ controls for the effect of size. While negatively related to the cost of equity capital (Gebhardt et al., 2001; Francis et al., 2005), $\beta_{S M B}$ being the loading against the return in the portfolio of small firms minus large firms is expected to load positively with the cost of capital (Dhaliwas et al., 2005; 2006). iii) $\beta_{H M L}$ is a proxy for the bookto-market ratio and consistent with the predictions in literature expected to load with a positive 
coefficient. Second, we control for leverage, estimated as the long-term debt divided by (total assets less book value of stockholders equity plus the market value of equity), which expect to load with a positive sign (consistent with the predictions in Modigliani and Miller, 1958; Hamada, 1969; and findings in Fama and French, 1992; Gode and Mohanram,2003; Boston and Plumlee,2005; Dhaliwal et al., 2006). Third, consistent with the literature, we also include two widely used controls for analyst earnings forecast attributes. Coefvar is the standard deviation of one-year analyst earnings forecasts scaled by one-year mean earnings forecasts, which is expected to load with positive sign consistent with the literature (Gode and Mohanram, 2003; Dhaliwal et al., 2006). Growth is the five-year mean earnings growth forecast from I/B/E/S recorded in June of each year and expected to load with positive sign ((Gode and Mohanram, 2003; Lee et al., 2007). We also control for industry effects by correcting our standard errors for industry and industry effects for robustness.

\subsection{Descriptive Statistics}

Table 1 provides descriptive statistics for all explanatory variables and their pair-wise correlations. Panel A presents statistical properties of individual explanatory variables. The extreme observations in explanatory variables were handled individually instead of winsorizing (due to the small sample size), e.g., leverage is truncated at $99 \%$ of total capital. Panel B of Table 1 provides Pearson correlation coefficients between regression variables. Because of the small sample size, some explanatory variables show slightly large correlations. However, these correlations are not large enough to cause problems with multicollinearity.

\section{Empirical Results}

\subsection{Litigation and Cost of Equity}

First, we test our predictions regarding the effect of litigation-triggering restatements on the cost of equity using simple univariate tests. We observe that in $67 \%$ of all restatements, firms experience an increase in the cost of equity. However, in $83 \%$ percent of restatements resulting in litigation, firms experience increase in the cost of equity. Fifty-seven percent of firms that do not face litigation after restatements experience increase in the cost of equity. As expected, this 
observation implies that restatements resulting in litigation are more likely to have an adverse impact on the firm's post-restatement cost of equity capital. ${ }^{7}$

Furthermore, on average, we observe that the magnitude of the increase in the cost of capital is greater for sued firms than for non-sued firms. We formally present and test the differences in the cost of equity between the firms with post-restatement litigation and no litigation in Table 2. In panels $A, B$, and $C$ respectively, We estimate the average and standard deviation of cost of equity $(K)$, cost of equity in excess of the three-month U.S. Treasury Bill yield (RP3), and the cost of equity in excess of the ten-year U.S. Treasury Bond yield (RP10). The latter two proxies (i.e., RP3 and RP10) are expected to account for the time variation in nominal cost of equity (Hail and Leuz, 2006). First, we compare the average of the cost of equity estimates during the three months before the restatement event - the first two rows in each of the three panels of Table 2 represent these comparisons. In this table, defendant firms have a slightly higher cost of equity than non-sued firms even before the restatement. However, the magnitude of this difference is small (about sixty basis points). Second, we compare the average of the cost of equity estimates during the three months after the restatement event - the second set of two rows in each of the three panels represents these comparisons. As expected, defendant firms have substantially higher costs of equity compared to non-sued firms after the restatement. The magnitude of this difference is high (over 350 basis points) and consistent with the view in the literature that restatement-related litigation costs are generally higher than the costs of any other litigation-triggering events (e.g., Jones and Weingram, 1997).

Finally, we compare the change in the average of the cost of equity estimates postrestatement relative to pre-restatement. The third set of two rows in each of the three panels represents these comparisons. The results show that both types of restating firms experience an

\footnotetext{
7 Since our implied cost of equity models have forecasted earnings and earnings growth as numerator, our models allow us to control for any change in forecasted future cash flows while estimating cost of equity capital. Thus, an increase in cost of equity capital is net of any effect in firm valuation through cash flows, and it allows us to unravel true effect in cost of equity capital more precisely. In a cursory analysis, we do check the effect of litigation in one year ahead earnings per share (EPS1) and long term growth rate forecast (Growth). We find that the post re-statement both EPS1 and Growth decline for all firms on average, however, average decline (particularly in Growth) is significantly higher for the firms facing litigation. This analysis suggests that for the firms facing litigation both the negative effect in cash flows and positive effect in discount rate is higher than those of the firms not facing post restatement litigation.
} 
increase in the cost of equity after restatement. The increase is about forty basis points for nonsued firms and significant at the $10 \%$ level assuming a one-tailed test. However, the increase in the cost of equity is over 350 basis points for firms that are sued after restatement and significant at better than $1 \%$ level. Collectively, these univariate tests provide some initial evidence in support of our hypothesis that litigation is the primary cause of the increase in the cost of equity after restatement. Below, we more formally test whether these relationships persist after accounting for major determinants of a firm's cost of equity capital.

Table 2, Panels D and E also reports changes in analyst expectations of one year ahead earnings per share (EPS1) and long-term earnings growth (Growth), respectively. EPS1 and Growth before restatement are estimated during three month period ( -3 months and -1 months) relative to restatement. Similarly, EPS1 and Growth after restatement are also estimated during a three month period ( +1 months and +3 months) relative to restatement. We find that analysts revise their forecast of EPS1 and Growth downwards for both sued and non-sued sub-samples. However, the post re-statement downwards revision is statistically significant only for sued sub-sample. ${ }^{8}$ Overall our results indicate that litigation risk is priced both through cash flow and cost of capital channels.

A potential concern with the interpretation of our results is that restatements that prompt a larger share price decline are likely to influence both the equity cost of capital and the likelihood of litigation. To address this endogeneity concern, we perform an analysis of the cost of capital for a sub-sample of sued and non-sued restating firms matched on restatement announcement return (CAR01). ${ }^{9}$ CAR01 is the market model cumulative abnormal return for the days zero and plus one relative to restatement. We estimated these cumulative abnormal returns based on the market model parameters estimated over a 250 days ending on day -46 relative to restatement. The daily return on CRSP value-weighted index are the proxies for the market returns. The mean of CAR01 equals $-18 \%$ for sued restating firms, while it is $-4 \%$ for non-sued restating firms. Table 3 shows that the match was successful because the difference in

\footnotetext{
${ }^{8}$ Results are similar when we analyze percent change in all variables. For example, for Growth, percent change is calculated as Growth at time $\mathrm{t}+1$ less Growth at time $\mathrm{t}$ divided by Growth at time $\mathrm{t}$.

${ }^{9}$ Only the pairs with CAR01 within $1 \%$ are considered a successful match, which results in 24 pairs comprised of a unique firm facing post restatement litigation and a matching firm not facing post restatement litigation.
} 
CAR01 between sued and non-sued restatements is not significant for this sub-sample and the average CAR01 equals $-10 \%$. We find that the full sample results hold for this sub-sample: cost of equity capital increases for both sued and non-sued firms, yet the increase in the cost of equity capital is considerably higher for sued firms.

\section{Empirical model:}

$$
\text { Kor } \Delta K=\alpha_{0}+\alpha_{1} \text { Litigation }+\alpha_{2+1} \text { Controls }+\varepsilon
$$

We specify the regression variables as follows:

$$
\begin{aligned}
& K= \begin{array}{l}
\text { Implied cost of equity capital based on methodology discussed in } \\
\text { section } 2.1 ;
\end{array} \\
& \Delta K= \begin{array}{l}
\text { Post-restatement } \mathrm{K} \text { less pre-restatement } \mathrm{K} ; \\
\text { Litigation }=
\end{array} \\
& \begin{array}{l}
\text { An indicator variable that equals one if the firm has been sued as a } \\
\text { result of a restatement as discussed in section } 2.2 ;
\end{array} \\
& \text { Controls }=\begin{array}{l}
\text { A set of firm- and country-level control variables discussed in section } \\
2.3 ;
\end{array} \\
& \varepsilon=\text { An error term. }
\end{aligned}
$$

Table 4 provides the main results of this study. As usual, in cross-sectional regressions, unspecified heteroskesdasticity is likely to affect our results. Therefore, we initially estimate robust standard errors using the White estimator. In each model, we use three different dependent variables representing the firm's cost of equity $(K)$, the cost of equity in excess of the yield on three-month U.S. Treasury Bills (RP3), and the cost of equity in excess of the yield on ten-year U.S. Treasury Bonds (RP10). The explanatory variables include an indicator for litigation and six major determinants of the cost of equity capital. Our base model includes three specifications in the first three columns, each including the cost of equity before the event, after the event and after less before the event. The coefficient of Litigation is positive but not significant before the event, but is positive and significant at the $1 \%$ level after the event. This result suggests that, while investors might capitalize losses prior to litigation as found in Gande and Lewis (2006), they increase the cost of equity only after the restatement announcement. Moreover, consistent with our predictions, we find that the coefficient on Litigation is positive and significant at the $1 \%$ level when we account for the increase in the cost of equity after the event (after less before). In the latter six models, we repeat our analysis using RP3 and RP10, respectively, and report similar and robust results. 
In Table 4, we also find that control variables generally load with the predicted signs in both the before and after regressions with a few exceptions. For the after less before regressions, we do not make a prediction for control variables, but we nevertheless control for them. First, we report results for the Fama-French risk factors. $\beta_{M K T}$ is the proxy for firm market risk, which is not significant and thus consistent with Gebhardt et al. (2001). $\beta_{S M B}$, our proxy for size which measures the degree of information availability about a firm, is positive and significant, consistent with Fama and French (1992) and Dhaliwal et al. $(2005,2006)$. $\beta_{H M L}$ is our proxy for the book-to-market ratio. The coefficient on $\beta_{H M L}$ is positive (as expected) and significant in the before and after regressions, implying that higher book-to-market value firms have higher expected returns. Both the literature that uses $\beta_{H M L}$ as the proxy for firm book-to-market related risk (Dhaliwal et al., 2005, 2006) or a direct measure of the book-to-market value ratio (e.g., Gode and Mohanram, 2003; Botosan and Plumlee, 2005; Hail and Leuz, 2006) report positive cost of capital effects of higher book-to-market ratios. Second, the estimate of the coefficient on leverage is generally positive but its significance varies across models, except for a few cases where it is negative but insignificant at higher than the $10 \%$ level. We predicted a positive sign for this variable based on analytical (Modigliani and Miller, 1958; Hamada, 1969) and empirical (Fama and French, 1992; Gode and Mohanram, 2003; Boston and Plumlee, 2005; Dhaliwal et al., 2006; Guedhami and Mishra, 2007; among others) literature. Third, both proxies for analyst earnings forecast attributes also have positive signs (as predicted), consistent with the literature. Overall, our findings suggest that our cost of equity estimates generally exhibit the expected relationships with common risk factors even though our sample size is small. Moreover, the insignificant coefficient of Litigation before financial restatements in the first, fourth, and seventh columns of Table 4, and positive and highly significant coefficients in after restatement and after less before restatement regressions provides strong evidence that the market prices a litigation associated with financial restatements. These results substantially corroborate our predictions and univariate results presented at the beginning of this section. Based on the coefficient of Litigation in the After less Before regressions, we estimate the economic effect of post-restatement litigation as an increase of about 259 basis points in the cost of equity capital.

\subsection{Robustness Tests}

In this section, we perform several sensitivity tests of the results presented in Table 4 to examine whether our core evidence that litigation-triggering financial restatements increase the 
cost of equity is robust. Some robustness tests are reported in Tables 5 through 9 and others are unreported. Overall, these tests confirm our baseline analysis that the post-restatement increase in the cost of equity is substantially higher for litigation-triggering restatements than restatements that do not result in litigation.

First, the effects of litigation-triggering restatements are likely to be different across industries. For example, the prior literature has shown that regulated, financial, technology, and retail firms face a higher probability of litigation (Field, Lowry, and Shu, 2005; Gande and Lewis, 2007). Therefore, one concern is that an excessive concentration of firms from certain industries may have affected our results. We mitigate this concern by correcting the standard errors by clustering at the industry level. Results reported in Table 5 continue to support our hypothesis. In Table 6, we repeat the analysis by correcting standard errors for both unspecified heteroskesdasticity and clustering by industry. Our results are robust to this correction. Furthermore, in unreported results, we continue to find robust results when controlling for the industry using dummy variables (at one-digit sic following John et al., 2008) and using the industry average cost of capital.

Second, in our main regressions in Table 7, we use the specifications employed in Dhaliwal et al. (2006) by choosing the Fama-French three factors to represent three major risk factors used in the literature. In Table 8 , we repeat our tests by using more traditional proxies for these risk factors: i) beta from the single factor CAPM instead of $\beta_{M K T}$ to represent market risk, ii) the number of sell-side analysts covering the firm as a measure of firm size and information availability instead of $\beta_{S M B}$, and iii) market-to-book ratio as a proxy for market anomalies instead of $\beta_{H M L}$. Our core results are robust to the use of these proxies. Moreover, the use of these variables also mitigates a concern that high correlation between the Fama-French factors and two other firm characteristics as presented in Panel B of Table 9 might have affected our core results. ${ }^{10}$

\footnotetext{
${ }^{10}$ Apart from these corrections, in untabulated robustness tests we also control for a) firm's natural log of total assets in place of $\beta_{S M B}$. Apart from this, the literature suggests firms' agency problems and corporate governance and firm age may affect cost of equity. Therefore, we control for firm age measured as restatement year less the first year the firm appeared in the Centre for Research in Securities Prices (CRSP) database and we use CEO_Ownership (as in Kim and Lu, 2011, missing values replaced with zero) as the proxy of firm's agency problems as higher ownership of CEO may imply lower agency problems. In controlling for these variables separately our results continue to hold.
} 
Third, in our main tests, we compare the cost of equity for three months before and three months after the event month. One may argue that our results may be the outcome of our choice of the event window and that the increase in the cost of equity as seen in our tests is simply a reflection of the short-term market reaction to these events. We mitigate this concern by comparing the cost of equity for the four to $\operatorname{six}(+4$ to +6$)$ months after the restatement month with the cost of equity for the four to six ( -4 to -6$)$ months before the restatement month. Our results (unreported) are robust to this change in the event window.

Fourth, following prior research, we compute the implied cost of equity under two major assumptions. First, cost of equity estimates are derived by truncating the expected dividend payout ratio by $50 \%$ to $100 \%$ assuming that, in the long-run, firms are expected to distribute earnings back to shareholders (see Claus and Thomas, 2001). We relax this assumption and re-estimate the cost of capital by fixing the lower bound of the expected dividend payout ratio at $25 \%$ and by replacing the expected dividend payout of firms falling below this threshold with the industry (Fama-French forty-eight classification) average dividend payout ratio. Second, we use the industry median expected return on equity (ROE) estimated as forecasted earnings per share for year $1\left(\right.$ FEPS $\left._{1}\right)$ divided by book value per share at the beginning of the year $\left(\mathrm{BV}_{0}\right)$ - to estimate $\mathrm{FEPS}_{4}$ to $\mathrm{FEPS}_{12}$, used in our initial estimates of the cost of equity under the GLS model. We reproduce our cost of equity estimates based on the GLS model and instead use the industry median of realized ROE - estimated as realized fiscal year end earnings per share $\left(\mathrm{EPS}_{0}\right)$ divided by $\mathrm{BV}_{0}$. In unreported results, using these different cost of equity estimates does not affect our conclusions.

Fifth, we replicate our core results reported in Table 4 using specifications in Hribar and Jenkins (2004). The control variables are core, which takes the value of one if the restatement relates to core earnings and zero otherwise, company, which takes the value of one if the restatement is initiated by the company and zero otherwise, auditor, which takes the value of one if the restatement is initiated by the auditor and zero otherwise, sec, which takes the value of one if the restatement is initiated by the SEC and zero otherwise, size, defined as the logarithm of total sales, and leverage and growth, which are calculated as defined earlier.11 The

\footnotetext{
${ }^{11}$ Forty-three of the sample of ninety-one restatements are restatements of core accounts, thirty-five are initiated by an auditor, forty are initiated by the SEC, and seven are initiated by the company.
} 
results reported in Table 8 continue to support our hypothesis that the post-restatement change in the cost of equity is positively associated with the litigation-triggering restatement.

We further replicate Table 8 after controlling for other characteristics of restatements, such as the magnitude of the mistake (measured as restated net income less originally reported net income divided by the absolute value of originally reported net income), number of periods restated, and an indicator variable to differentiate restatements that involved only quarterly and not annual reports. Our results are robust to adding these additional controls, and the coefficients on all of these extra controls, except for number of periods restated, are not statistically significant. The coefficient on number of periods restated is positive and significant at $10 \%$ level, which suggests that the credibility loss is substantially higher for firms that restate multiple financial statements.

Finally, following Hail and Leuz (2006) and Dhaliwal et al. (2006), we rely on the average of the cost of equity estimates of four widely used models to estimate our main proxy for the cost of equity $(K)$ to reduce the concern of spurious results arising from the use of a single model. In Table 9, we replace $K$ with the cost of equity estimated using each of these four models ( $\mathrm{K}_{\mathrm{O}}, \mathrm{K}_{\mathrm{ES}}, \mathrm{K}_{\mathrm{CT}}$ and $\left.\mathrm{K}_{\mathrm{GLS}}\right)$. All models except for $\mathrm{K}_{\mathrm{CT}}$ show that, before the restatement, the cost of equity of firms with litigation-triggering restatements is not significantly different from zero. However, $\mathrm{K}_{\mathrm{CT}}$ shows that these firms' cost of equity is about $1.4 \%$ higher than the cost of equity of the non-litigation subsample even before restatement. However, supporting our main hypothesis, all four models give robust results in the after and after less before regressions that the cost of equity of the firms facing post-restatement litigation increases significantly. Overall, these results provide strong assurance that our inferences are not driven by the distinctive characteristics of any single model.

\section{Conclusion}

We empirically examine whether the cost of equity - implied by analyst earnings forecasts and current prices - increases for firms that face litigation subsequent to a financial restatement, and whether market anticipates litigation before restatement announcement as evident from its effect on financing costs. We estimate the cost of equity three months prior to a restatement and after a restatement using four models of implied cost of equity: Easton (2004), 
Ohlson and Juettner-Nauroth (2005), Gebhardt et al., (2001) and Claus and Thomas (2001). We find that the cost of equity increases after restatement for all firms. However, the increase in cost of equity is substantially greater for firms facing litigation as a result of the restatement. The economic effect of post-restatement litigation is an increase in the firm's cost of equity of about 259 basis points. In cross-sectional tests, we also find that litigation is an important determinant of the cost of equity after restatement when controlling for other determinants of the cost of equity. However, we also find that investors do not significantly adjust the risk premium for firms facing litigation prior to a restatement announcement, suggesting that market does not anticipate litigation before restatement announcement. Overall, our findings suggest that the cost of equity is an important channel through which litigation-triggering restatements affect firms.

Our findings extend prior research on the impact of financial restatements on the cost of equity in several ways. This is the first paper to investigate the effect of litigation-triggering restatements on the cost of equity. We extend Hribar and Jenkins (2004) by showing that the increase in the cost of capital is much more pronounced for firms facing litigation as a result of the restatement. While Hribar and Jenkins primarily rely on cost of equity estimates from three individual models, we use the average cost of equity estimates from four different models, a method which is popular in more recent literature (e.g., Dhaliwal et al., 2006). Our methodology is more robust than that previously used to study the impact of restatements on the cost of equity. We also contribute to the literature on litigation. We complement the findings of Gande and Lewis (2006), who show that investors capitalize losses related to litigation prior to the announcement of litigation. We find robust evidence for the notion that, while investors may account for litigation before the litigation event, they do not adjust the risk premium prior to the announcement of a restatement by firms that are sued as a result of a restatement. While our results are strong, much remains to be done in this line of research. For example, by extending the sample substantially one may be able to study several alternative explanations, in particular, how the effect of litigation varies with the type of litigation. 


\section{Appendix A.1 \\ Cost of Equity Models ${ }^{12}$}

$\mathrm{K}_{\mathrm{MM}}=$ Cost of equity estimate of the model as identified in the subscript, for example, ' $\mathrm{MM}^{\prime}={ }^{\prime} \mathrm{CT}$ ' for Claus and Thomas (2001) model; FEPS ${ }_{\mathrm{T}+\mathrm{t}}=\mathrm{I} / \mathrm{B} / \mathrm{E} / \mathrm{S}$ consensus earnings forecast for the $\mathrm{t}^{\text {th }}$ year, where earnings statistics released at fiscal year end-month plus 6 months; $\mathrm{P}_{\mathrm{T}}=\mathrm{I} / \mathrm{B} / \mathrm{E} / \mathrm{S}$ market price coinciding with the release date of FEPS for the estimation year; $B_{T}=$ Book value per share for the estimation year, $B_{T+i}=B_{T+i-1}+F E P S_{T+i}-D_{T+i} ; D_{\mathrm{T}+\mathrm{i}}=\mathrm{FEPS}_{\mathrm{T}+\mathrm{i}}{ }^{*}$ Dividend Payout. Dividend payout is recorded at the fiscal year end and is replaced in loss-making firms by the mean of the industry dividend payout according to the Fama-French 48 industry classifications estimated using the sample of non-loss making firms. Dividend payout for use with the Claus and Thomas (2001) model is fixed at $50 \%$ for all firms, consistent with Claus and Thomas (2001).

Model 1: KOJ -Ohlson and Juttner-Nauroth (2005 OJ) as implemented in Gode and Mohanram (2003)

$$
\begin{gathered}
K_{O J}=A+\sqrt{A^{2}+\frac{F E P S_{T}+1}{p_{T}}\left[g_{2}-(y-1)\right]} \\
A=\frac{1}{2}\left((y-1)+\frac{D_{T+1}}{P_{T}}\right), g_{2}=\frac{F E P S T+2-F E P S T+1}{F E P S T+1}, y=\text { a constant which is equal to 1+ long-term }
\end{gathered}
$$

growth rate, the long-term growth rate $(y-1)$ was fixed at the annualized 10-year U.S. Treasury Bond yield minus 3\%, consistent with Dhaliwal et al. (2006). We keep observations that return a cost of equity estimate with $0 \%$ to $100 \%$ to be consistent with other models as described below.

Model2: $K_{C T}$-Claus and Thomas (2001 CT)

$$
P_{T}=B_{T}+\frac{F E P S_{T+1}-K_{C T} B_{T}}{\left(1+K_{C T}\right)}+. .+\frac{F E P S_{T+5}-K_{C T} B_{T+4}}{\left(1+K_{C T}\right)^{5}}+\frac{\left(F E P S_{T+5}-K_{C T} B_{T+4}\right)\left(1+g_{n}\right)}{\left(K_{C T}-g_{n}\right)\left(1+K_{C T}\right)^{5}}
$$

The forecasts beyond two years are taken as reported where available, otherwise they were generated based on the five-year consensus growth rate forecast or the average growth in $F E P S_{1}$ to $F E P S_{3}$. The longterm growth rate beyond five years $\mathrm{g}_{\mathrm{n}}=$ annualized US Treasury bond yield minus $3 \%$. Finally, we manually search for $K_{C T}$ that satisfies equation 2 by searching $K_{C T}$ within 0 to $100 \%$. We exclude observations that do not converge.

Model 3: KGLS - Gebhardt, Lee and Swaminathan (2001 GLS)

$$
P_{T}=B_{T}+\frac{F E P S_{T+1}-K_{G L S} B_{T}}{\left(1+K_{G L S}\right)}+\ldots .+\frac{F E P S_{T+t}-K_{G L S} B_{T+t-1}}{\left(1+K_{G L S}\right)^{t}}+\ldots+\frac{F E P S_{T+t+1}-K_{G L S} B_{T+t}}{K_{G L S}\left(1+K_{G L S}\right)^{t}}
$$

$F E P S_{\mathrm{T}+4}$ to $F E P S_{\mathrm{T}+12}$ is forecasted such that $R O E$ gradually and linearly converges to industry $R O E$ in the $12^{\text {th }}$ year. Industry $R O E$ is estimated as the five-year moving average of annual median of fiscal year end $R O E$ of all firms in an industry based on Fama-French 48 Industry classifications (4 years for 1990). Growth in earnings after the $12^{\text {th }}$ year is assumed to be zero. We manually search for $K_{G L S}$ within 0 to $100 \%$.

Model 4: KES Easton -(2004 ES):

$$
P_{T}=\frac{F E P S_{T+2}+K_{E S} \cdot D_{T+1}-F E P S_{T+1}}{K_{E S}^{2}}
$$

We manually search of $K_{E S}$ within 0 to $100 \%$.

12 This section is largely adapted from other papers, such as Guedhami and Mishra (2007). 


\section{APPENDIX A.2}

Variables, definitions, and sources

\begin{tabular}{|c|c|c|}
\hline Variable & Description & Source \\
\hline K & $\begin{array}{l}\text { Implied cost of equity estimated as the arithmetic average of (Koj, } \\
\text { Kct, Kgls, Kes as described in Appendix A.1) }\end{array}$ & Estimated \\
\hline RP3 & K less annualized Yield on three-month US Treasury Bills & $\begin{array}{l}\text { Estimated / Federal } \\
\text { Reserve }\end{array}$ \\
\hline RP10 & K less annualized Yield on ten-year US Treasury Bonds & $\begin{array}{l}\text { Estimated/ Federal } \\
\text { Reserve }\end{array}$ \\
\hline$\beta_{M K T}$ & $\begin{array}{l}\text { Loading of excess equity return in the market factor of the Fama- } \\
\text { French (1993) three factor model. A proxy for a firm's market risk. }\end{array}$ & CRSP/Estimated \\
\hline$\beta_{S M B}$ & $\begin{array}{l}\text { Loading of excess equity return in the small minus large (SMB) } \\
\text { factor of the Fama-French (1993) three factor model. A proxy for a } \\
\text { firm's size related risk. }\end{array}$ & CRSP/Estimated \\
\hline$\beta_{H M L}$ & $\begin{array}{l}\text { Loading of excess equity return in the high market to book minus } \\
\text { low market to book (HML) factor of the Fama-French (1993) three } \\
\text { factor model. A proxy for market to book value related risk. }\end{array}$ & CRSP/Estimated \\
\hline Leverage & $\begin{array}{l}\text { Total Debt (Long-term Debt - item A9 plus Debt in Current } \\
\text { Liabilities - item A34) divided by Total Invested Capital - item A37 } \\
\text { calculated for the last fiscal year before restatement. }\end{array}$ & $\begin{array}{l}\text { Compustat/Research } \\
\text { Insight }\end{array}$ \\
\hline Coefuar & $\begin{array}{l}\text { Standard deviation of estimated first year earnings per share } \\
\text { divided by mean earnings per share forecast for the first year } \\
\text { calculated for the month of restatement unless otherwise } \\
\text { indicated. }\end{array}$ & $\mathrm{I} / \mathrm{B} / \mathrm{E} / \mathrm{S}$ \\
\hline Growth & $\begin{array}{l}\text { I/B/E/S five-year earnings growth rate where available, } \\
\text { otherwise estimated as growth in forecasted earnings from Year } 1 \\
\text { to Year } 3 \text { calculated for the month of restatement unless otherwise } \\
\text { indicated. }\end{array}$ & $\mathrm{I} / \mathrm{B} / \mathrm{E} / \mathrm{S}$ \\
\hline EPS1 & I/B/E/S forecast of one-year ahead earnings. & $\mathrm{I} / \mathrm{B} / \mathrm{E} / \mathrm{S}$ \\
\hline Litigation & $\begin{array}{l}\text { An indicator variable that equals one if the firm has been sued as a } \\
\text { result of a restatement }\end{array}$ & Estimated \\
\hline
\end{tabular}




\section{References:}

Agrawal, A. and S. Chadha, 2005. Corporate governance and accounting scandals, Journal of Law and Economics 48, 371-406.

Agrawal, A. and T. Cooper, 2007. Corporate governance consequences of accounting scandals: Evidence from top management, CFO and Auditor Turnover, University of Alabama Working Paper.

Bardos, K.S., 2011. Quality of Financial Information and Liquidity. Review of Financial Economics, 20, 49-62.

Bardos, K. S., J. Golec and J. Harding, 2011. Do investors see through mistakes in reported earnings? Journal of Financial and Quantitative Analysis 46 (6), 1917-1946.

Bardos, K. S., J. Golec and J. Harding, 2013. Litigation risk and market reaction to financial statement restatements, Journal of Financial Research 36(1), 19-42.

Bardos, K. S., and N. Zaiats, 2012. Financial Statement Restatements and Equity and Debt Issuance, Accounting and Finance 52, 77-108.

Barniv, R. R., and J. Cao, 2008. Does information uncertainty affect investors' responses to analysts' forecast revisions? An investigation of accounting restatements, Journal of Accounting and Public Policy 28, 328-348.

Bandyopadhyay, S., L. Brown and G. Richardson, 1995. Analysts' use of earnings forecasts in predicting stock returns: Forecast horizon effects, International Journal of Forecasting 11, 429-445.

Botosan, C. and M. Plumlee 2005. Assessing alternative proxies for the expected risk premium, The Accounting Review 80, 21-53.

Bradley, D., B. Cline and Q. Lian. 2010. Class action lawsuits and executive option exercise behavior. University of South Florida working paper

Bradshaw, M., 2004. How do analysts use their earnings forecasts in generating stock recommendations? The Accounting Review 79, 25-50. 
Burks, J., 2010. Disciplinary measures in response to restatements after Sarbanes-Oxley, Journal of Accounting and Public Policy 29, 195-225.

Chalmers, K., Naiker, V. and F. Navissi, 2011. Earnings quality and Rule 10b-5 securities class action lawsuits, Journal of Accounting and Public Policy 31, 22-43.

Claus, J. and J. Thomas, 2001. Equity premia s low as three percent? Evidence from analysts' earnings forecasts for domestic and international stock markets, Journal of Finance 56, 1629-1666.

Desai, H., C. Hogan and M. Wilkins, 2006. The reputational penalty for aggressive accounting: earnings restatements and management turnover, The Accounting Review 81, 83-112.

Dhaliwal, D., L. Krull, O. Li and W. Moser, 2005. Dividend taxes and implied cost of equity capital, Journal of Accounting Research 43, 675-708.

Dhaliwal, D., S. Heitzman and O. Li, 2006. Taxes, leverage, and the cost of equity capital, Journal of Accounting Research 44, 691-723.

Easley, D. and O'Hara, M., 2004. Information and the cost of capital, Journal of Finance 59, 15531483.

Easton, P. 2004. PE ratios, PEG ratios, and estimating the implied expected rate of return on equity capital, The Accounting Review 79, 73-95.

Edwards, E. and P. Bell, 1961. The theory and measurement of business income, Berkeley, CA: University of California Press.

El Ghoul, S., O. Guedhami , C. Kwok, and D. Mishra, 2011. Does corporate social responsibility affect cost of equity capital? Journal of Banking E Finance 35: 2388-2406.

Elton, E., 1999. Presidential address: Expected return, realized return, and asset pricing tests, Journal of Finance 54, 1199-1220.

Ertimur, Y., J. Sunder and S. Sunder, 2007. Measure of measure: The relation between forecast accuracy and recommendation profitability of analysts, Journal of Accounting Research 45, 567606. 
Fama, E. and K. French, 1992. The cross sections of expected stock returns, Journal of Finance 47, 427-466.

Fama, E. and K. French, 1993. Common risk factors in the returns on bonds and stocks, Journal of Financial Economics 33, 3-56.

Fama, E. and K. French, 1997. Industry costs of equity, Journal of Financial Economics 43, 153-194.

Fama, E. and K. French, 2004. The capital asset pricing model: theory and evidence, Journal of Economic Perspectives 18, 25-46.

Feltham, G. and J. Ohlson, 1995. Valuation and clean surplus accounting for operating and financial activities, Contemporary Accounting Research 11, 689-731.

Field, L., M. Lowry and S. Shu., 2005. Does disclosure deter or trigger litigation, Journal of Accounting and Economics 39, 487-507.

Francis, J., R. LaFond, P. Olsson and K. Schipper, 2005. The market pricing of accruals quality, The Journal of Accounting and Economics 39, 295-327.

Francis, J., D. Philbrick and K. Schipper. 1994. Shareholder litigation and corporate disclosures, Journal of Accounting Research 32, 137-164.

Francis, J. and L. Soffer, 1997. The relative informativeness of analysts' stock recommendations and earnings forecast revisions, Journal of Accounting Research 35, 193-211.

Gande, A. and C. Lewis, 2007. Shareholder initiated class action lawsuits: shareholder wealth effects and industry spillovers, Journal of Financial and Quantitative Analysis 44, 823-850.

Géczy, C., B. Minton and C. Schrand, 1997. Why firms use currency derivatives? Journal of Finance 52, 1323-1354.

General Accounting Office, 2002. Financial statement restatements: trends, market impacts, regulatory responses, and remaining challenges, GAO-03-138.

Gephardt, W., C. Lee and B. Swaminathan, 2001. Toward an implied cost of equity, Journal of Accounting Research 39, 135-176. 
Geiger M.A., K. Raghunandan and D. V. Rama, 2006. Auditor decision-making in different litigation environments: The Private Securities Litigation Reform Act, audit reports and audit firm size, Journal of Accounting and Public Policy 25, 332 - 353.

Gleason, C., N. Jenkins and W. Johnson, 2005. Financial statement credibility: the contagion effects of accounting restatements, University of Iowa Working Paper.

Graham, J., S. Li and J. Qiu, 2008. Corporate misreporting and bank loan contracting, Journal of Financial Economics 89, 44-61.

Griffin, P. 2003. A league of their own? Financial analysts' responses to restatements and corrective disclosures. Journal of Accounting, Auditing, E Finance 18, 479-518.

Griffin, P., J. Grundfest and M. Perino, 2004. Stock price response to news of securities fraud litigation: an analysis of sequential and conditional information, ABACUS 40, 21-48.

Gode, D. and P. Mohanram, 2003. Inferring the cost of equity using the Ohlson-Juettner Model, Review of Accounting Studies 8, 399-431.

Guedhami, O. and D. Mishra, 2009. Excess control, corporate governance, and implied cost of equity: International evidence, Special Issue of The Financial Review 4, 489-524

Hail, L. and C. Luez, 2006. International differences in the cost of equity capital: Do legal institutions and securities regulation matter? Journal of Accounting Research 44, 485-531.

Hamada, R., 1969. Portfolio analysis, market equilibrium, and corporation finance, Journal of Finance 24, 13-31.

Hribar, P. and N. Jenkins, 2004. The effect of accounting restatements on earnings revisions and the estimated cost of capital, Review of Accounting Studies 9, 337-356.

John, K., L. Litov, \& B. Yeung, 2008. Corporate governance and risk-taking, The Journal of Finance 63, 1679-1728.

Johnson, M., K. Nelson and A. Pritchard, 2007. Do the merits matter more? The Impact of the private securities litigation reform act, Journal of Law Economics and Organization 23, 627-652. 
Jones, C. and E. Weingram, 1997. The effects of insider trading, seasoned equity offerings, corporate announcements, accounting aestatements, and SEC enforcement Actions on 10b-5 litigation risk. Stanford University Graduate School of Business Working Paper Series.

Karpoff, J., S. Lee and G. Martin, 2007a. The Consequences to managers for financial misrepresentation, Journal of Financial Economics 88, 193-215.

Karpoff, J., S. Lee and G. Martin, 2007b. The legal penalties for financial misrepresentation, University of Washington and Texas A\&M University Working Paper.

Kim H. and Y. Lu, 2011. CEO ownership, external governance, and risk-taking. Journal Financial Economics 102: 272-292.

Kim, J. W. and Y. Shi , 2011. Voluntary disclosure and the cost of equity capital: Evidence from management earnings forecasts, Journal of Accounting and Public Policy 30, 348-366.

Kravet, T. and T. Shevlin, 2010. Accounting restatements and information risk, Review of Accounting Studies 15, 264-294.

Lam, K. C. K., and Y. M., Mensah, 2006. Auditors' decision-making under going-concern uncertainties in low litigation-risk environments: Evidence from Hong Kong, Journal of Accounting and Public Policy 26, 706-739.

Lambert, R., C. Leuz and R. Verrecchia, 2007. Accounting information, disclosure, and the cost of capital, Journal of Accounting Research 45, 385-420.

Lee, C., D. Ng and B. Swaminathan, 2007. Testing international asset pricing using implied cost of capital, Journal of Financial and Quantitative Analysis, forthcoming.

Li, Y. 2009. Shareholder litigation, management forecasts, and productive decisions during the initial public offerings, Journal of Accounting and Public Policy 28, 1-15.

Li, H., M. Pincus and S. Rego, 2008. Market reaction to events surrounding the sarbanes-oxley act of 2002 and earnings management, Journal of Law \& Economics 51, 111-134.

Loh, R. and M. Mian, 2006. Do accurate earnings forecasts facilitate superior investment recommendations, Journal of Financial Economics 80, 455-483. 
Lowry, M. and S. Shu, 2002. Litigation risk and IPO underpricing, Journal of Financial Economics 65, 309-335.

Modigliani, F. and M. Miller, 1958. The cost of capital, corporation finance and the theory of investment, American Economic Review 48, 261-297.

Ohlson, J., 1995. Earnings, book value, and dividends in security valuation, Contemporary Accounting Research 11, 661-687.

Ohlson, J. and B. Juettner-Narouth, 2005. Expected EPS and EPS growth as determinants of Value, Review of Accounting Studies 10, 349-365.

Palmrose, Z-V, V. Richardson and S. Scholz, 2004. Determinants of market reaction to restatement announcement, Journal of Accounting and Economics 37, 59-89.

Palmrose, Z-V. and S. Scholz, 2004. The accounting causes and legal consequences of nonGAAP reporting: evidence from restatements, Contemporary Accounting Research 21, 139-180.

Pham, P., J. Suchard and J. Zein, 2007. Corporate governance, cost of capital and performance: evidence from Australian firms, Available at SSRN: http://ssrn.com/abstract=1015986

Wilson, W. 2008. An empirical analysis of the decline in the information content of earnings following restatements. The Accounting Review 83, 519-549. 
Exhibit 1

\section{Final Sample Attribution}

\begin{tabular}{lcc}
\hline Description & Restatements & Firms \\
\hline Manually collected financial restatement events & 537 & 496 \\
Matched with IBES \& Compustat in event year & 345 & 326 \\
$\begin{array}{l}\text { Have valid observations for the three months before and after } \\
\text { the event month }\end{array}$ & 332 & 313 \\
$\begin{array}{l}\text { Met all data requirements for cost of equity estimation } \\
\text { Valid cost of equity estimated at least once in the event window }\end{array}$ & 170 & 163 \\
$\begin{array}{l}\text { Valid cost of equity estimated either before or after restatement } \\
\text { Valid cost of equity estimated both before and after restatement } \\
\text { event }\end{array}$ & 163 & 161 \\
\hline \hline
\end{tabular}


Table 1

\begin{tabular}{lcccccccc}
\hline \multicolumn{1}{l}{ Panel A: Descriptive Statistics } & Mean & STDEV & Min & Q1 & Median & Q3 & Max & N \\
\hline Variable & 1.601 & 1.645 & 0.010 & 0.770 & 1.340 & 1.973 & 14.020 & 91 \\
\hline EPS1_Before & 1.526 & 1.707 & 0.040 & 0.670 & 1.197 & 1.620 & 14.190 & 91 \\
EPS1_After & -0.075 & 0.459 & -2.593 & -0.230 & 0.000 & 0.130 & 1.362 & 91 \\
EPS1_(Afterless Before) & 21.025 & 11.848 & 3.000 & 12.083 & 19.090 & 26.095 & 64.000 & 91 \\
Growth_Before & 20.336 & 11.647 & 3.000 & 12.000 & 19.030 & 24.000 & 64.000 & 91 \\
Growth_After & -0.689 & 2.337 & -12.115 & -1.397 & -0.173 & 0.390 & 6.250 & 91 \\
Growth_(After less Before) & 0.109 & 0.031 & 0.028 & 0.086 & 0.105 & 0.126 & 0.208 & 91 \\
K_Before & 0.125 & 0.057 & 0.029 & 0.095 & 0.111 & 0.140 & 0.443 & 91 \\
K_After & 0.016 & 0.042 & -0.070 & -0.004 & 0.006 & 0.029 & 0.287 & 91 \\
K_(Afterless Before) & 0.060 & 0.031 & -0.018 & 0.039 & 0.056 & 0.078 & 0.157 & 91 \\
rp3_Before & 0.077 & 0.057 & -0.019 & 0.049 & 0.063 & 0.091 & 0.396 & 91 \\
rp3_After & 0.017 & 0.042 & -0.045 & -0.003 & 0.008 & 0.031 & 0.287 & 91 \\
rp3_(After less Before) & 0.051 & 0.032 & -0.028 & 0.031 & 0.048 & 0.070 & 0.144 & 91 \\
rp3_Before & 0.068 & 0.057 & -0.024 & 0.035 & 0.054 & 0.085 & 0.386 & 91 \\
rp10_After & 0.017 & 0.042 & -0.059 & -0.004 & 0.007 & 0.029 & 0.287 & 91 \\
rp10_(Afterless Before) & 1.225 & 0.778 & -1.249 & 0.823 & 1.150 & 1.772 & 3.054 & 91 \\
$\beta_{\text {MKT }}$ & 0.663 & 0.884 & -0.950 & -0.010 & 0.521 & 1.111 & 3.908 & 91 \\
$\beta_{\text {SMB }}$ & 0.260 & 1.167 & -3.113 & -0.089 & 0.438 & 0.941 & 3.343 & 91 \\
$\beta_{\text {HML }}$ & 0.426 & 0.330 & 0.000 & 0.077 & 0.395 & 0.695 & 0.990 & 91 \\
Leverage & 0.111 & 0.224 & 0.000 & 0.018 & 0.034 & 0.088 & 1.000 & 91 \\
Coefvar & & & & & & & &
\end{tabular}

\begin{tabular}{|c|c|c|c|c|c|}
\hline \multicolumn{6}{|c|}{ Panel B: Correlation Coefficients } \\
\hline Variable & $\beta_{M K T}$ & $\beta_{S M B}$ & $\beta_{H M L}$ & Leverage & Coefvar \\
\hline$\beta_{S M B}$ & 0.26 & & & & \\
\hline$\beta_{\mathrm{HML}}$ & 0.40 & 0.19 & & & \\
\hline Leverage & 0.17 & -0.11 & 0.57 & & \\
\hline Coefvar & -0.03 & 0.15 & 0.01 & -0.04 & \\
\hline Growth & 0.05 & 0.17 & -0.51 & -0.51 & -0.06 \\
\hline
\end{tabular}

This table presents descriptive statistics for a sample of 91 restatements made between 1997 and July 2002. The sample of restatements was manually collected from Lexis-Nexis and cross-checked with a sample released by GAO 2002. For details of sample attribution, please see Exhibit 1. Appendix A.2 reports detailed definitions and data sources for our dependent variables $K, R P 3$, and $R P 10$ and all test and control variables. 
Table 2

Financial Restatement, Litigation and Implied Cost of Equity and Cash Flow Effect Univariate Analysis

\begin{tabular}{|c|c|c|c|c|c|c|}
\hline Variable & Time & Litigation & Mean & STDEV & $\mathrm{N}$ & T_Stat \\
\hline \multicolumn{7}{|l|}{ Panel A: K } \\
\hline \multirow{6}{*}{ K } & \multirow{2}{*}{ Before } & No & 0.106 & 0.028 & 56 & \\
\hline & & Yes & 0.113 & 0.036 & 35 & \\
\hline & \multirow{2}{*}{ After } & No & 0.110 & 0.037 & 56 & \\
\hline & & Yes & 0.148 & 0.074 & 35 & \\
\hline & \multirow{2}{*}{ After less Before } & No & 0.004 & 0.022 & 56 & $1.45^{*}$ \\
\hline & & Yes & 0.035 & 0.058 & 35 & $3.52^{* * *}$ \\
\hline \multicolumn{7}{|c|}{ Panel B: Growth } \\
\hline \multirow{6}{*}{ RP3 } & \multirow{2}{*}{ Before } & No & 0.058 & 0.029 & 56 & \\
\hline & & Yes & 0.064 & 0.036 & 35 & \\
\hline & \multirow{2}{*}{ After } & No & 0.062 & 0.038 & 56 & \\
\hline & & Yes & 0.101 & 0.074 & 35 & \\
\hline & \multirow{2}{*}{ After less Before } & No & 0.004 & 0.022 & 56 & $1.50^{*}$ \\
\hline & & Yes & 0.037 & 0.057 & 35 & $3.88^{* * *}$ \\
\hline \multicolumn{7}{|l|}{ Panel C: $K$} \\
\hline \multirow{6}{*}{ RP10 } & \multirow{2}{*}{ Before } & No & 0.049 & 0.029 & 56 & \\
\hline & & Yes & 0.056 & 0.035 & 35 & \\
\hline & \multirow{2}{*}{ After } & No & 0.054 & 0.037 & 56 & \\
\hline & & Yes & 0.092 & 0.074 & 35 & \\
\hline & \multirow{2}{*}{ After less Before } & No & 0.005 & 0.021 & 56 & $1.67^{* *}$ \\
\hline & & Yes & 0.036 & 0.057 & 35 & $3.76^{* * *}$ \\
\hline \multicolumn{7}{|c|}{ Panel D: EPS1 } \\
\hline \multirow{6}{*}{ EPS1 } & \multirow{2}{*}{ Before } & No & 1.390 & 0.948 & 56 & \\
\hline & & Yes & 1.939 & 2.348 & 35 & \\
\hline & \multirow{2}{*}{ After } & No & 1.369 & 1.011 & 56 & \\
\hline & & Yes & 1.778 & 2.440 & 35 & \\
\hline & \multirow{2}{*}{ After less Before } & No & -0.022 & 0.454 & 56 & -0.36 \\
\hline & & Yes & -1.161 & 0.460 & 35 & $-2.08^{* *}$ \\
\hline \multicolumn{7}{|c|}{ Panel E: Growth } \\
\hline \multirow{6}{*}{ Growth } & \multirow{2}{*}{ Before } & No & 18.855 & 10.800 & 56 & \\
\hline & & Yes & 24.497 & 12.757 & 35 & \\
\hline & \multirow{2}{*}{ After } & No & 18.594 & 10.869 & 56 & \\
\hline & & Yes & 23.124 & 12.449 & 35 & \\
\hline & \multirow{2}{*}{ After less Before } & No & -0.261 & 2.107 & 56 & -0.93 \\
\hline & & Yes & -1.372 & 2.549 & 35 & $-3.18^{* * *}$ \\
\hline
\end{tabular}

This table shows analyst forecasts of EPS1 and Growth, and estimates of the cost of capital K and risk premiums over 3-month US Treasury Bills (RP3) and 10-year US Treasury Bonds (RP10) for a sample of 91 restatements made between 1997 and July 2002. For details of sample attribution, please see Exhibit 1. Appendix A.2 reports detailed variable definitions. $* * *, * *$, and * denote statistical significance at the $1 \%, 5 \%, 10 \%$ levels, respectively for a one-tailed t-test. 
Table 3

Financial Restatement, Litigation and Implied Cost of Equity Univariate Analysis - Sample matched on CAR01

\begin{tabular}{|c|c|c|c|c|c|c|}
\hline Variable & Time & Litigation & Mean & STDEV & $\mathrm{N}$ & T_Stat \\
\hline \multicolumn{7}{|c|}{ Panel A: CAR01 } \\
\hline & & Yes & -0.099 & 0.098 & 24 & $-4.94^{* * *}$ \\
\hline CAR01 & Days $(0 ;+1)$ & No & -0.099 & 0.101 & 24 & $-4.82^{* \star *}$ \\
\hline Difference & & & 0.001 & 0.005 & 24 & 0.71 \\
\hline \multicolumn{7}{|l|}{ Panel B: K } \\
\hline & & No & 0.098 & 0.028 & 24 & \\
\hline & Before & Yes & 0.115 & 0.027 & 24 & \\
\hline & & No & 0.106 & 0.044 & 24 & \\
\hline & After & Yes & 0.143 & 0.071 & 24 & \\
\hline & & No & 0.028 & 0.063 & 24 & $1.58^{*}$ \\
\hline K & After less Before & Yes & 0.008 & 0.023 & 24 & $2.18^{* *}$ \\
\hline \multicolumn{7}{|c|}{ Panel C: RP3 } \\
\hline & & No & 0.048 & 0.029 & 24 & \\
\hline & Before & Yes & 0.065 & 0.028 & 24 & \\
\hline & & No & 0.057 & 0.045 & 24 & \\
\hline & After & Yes & 0.097 & 0.071 & 24 & \\
\hline & & No & 0.009 & 0.023 & 24 & $1.83^{* *}$ \\
\hline $\mathrm{RP3}$ & After less Before & Yes & 0.032 & 0.062 & 24 & $2.51^{* * *}$ \\
\hline \multicolumn{7}{|c|}{ Panel D: RP10 } \\
\hline & & No & 0.041 & 0.030 & 24 & \\
\hline & Before & Yes & 0.057 & 0.028 & 24 & \\
\hline & & No & 0.050 & 0.044 & 24 & \\
\hline & After & Yes & 0.088 & 0.071 & 24 & \\
\hline & & No & 0.010 & 0.021 & 24 & $2.24^{* *}$ \\
\hline RP10 & After less Before & Yes & 0.032 & 0.062 & 24 & $2.51^{* * *}$ \\
\hline
\end{tabular}

This table shows estimates of the cost of capital $\mathrm{K}$ and risk premiums over 3-month US Treasury Bills (RP3) and 10-year US Treasury Bonds (RP10) for a sample of 91 restatements made between 1997 and July 2002. The sample of restatements was manually collected from Lexis-Nexis and cross-checked with a sample released by GAO 2002. For details of sample attribution, please see Exhibit 1. Appendix A.2 reports detailed definitions and data sources for K, RP3, and RP10 and Litigation variables. 
Table 4

Financial Restatement, Litigation and Implied Cost of Equity

\begin{tabular}{|c|c|c|c|c|c|c|c|c|c|}
\hline Model & $(1)$ & (2) & (3) & (4) & (5) & (6) & (7) & (8) & (9) \\
\hline \multirow[t]{2}{*}{$\begin{array}{l}\text { Dependent } \\
\text { Variable }\end{array}$} & & K & & \multicolumn{3}{|c|}{ RP3 } & \multicolumn{3}{|c|}{ RP10 } \\
\hline & Before & After & $\begin{array}{l}\text { After } \\
\text { less } \\
\text { Before }\end{array}$ & Before & After & $\begin{array}{c}\text { After } \\
\text { less } \\
\text { Before }\end{array}$ & Before & After & $\begin{array}{l}\text { After } \\
\text { less } \\
\text { Before }\end{array}$ \\
\hline Constant & $\begin{array}{c}0.0891^{* * *} \\
{[8.40]}\end{array}$ & $\begin{array}{c}0.0687^{* * *} \\
{[3.66]}\end{array}$ & $\begin{array}{c}-0.0205 \\
{[-1.66]}\end{array}$ & $\begin{array}{c}0.0434^{* * *} \\
{[4.08]}\end{array}$ & $\begin{array}{l}0.0214 \\
{[1.14]}\end{array}$ & $\begin{array}{c}-0.0220^{*} \\
{[-1.79]}\end{array}$ & $\begin{array}{c}0.0347^{* * *} \\
{[3.19]}\end{array}$ & $\begin{array}{l}0.0132 \\
{[0.72]}\end{array}$ & $\begin{array}{c}-0.0215^{*} \\
{[-1.81]}\end{array}$ \\
\hline Litigation & $\begin{array}{l}0.0051 \\
{[0.87]}\end{array}$ & $\begin{array}{c}0.0310^{* * *} \\
{[2.83]}\end{array}$ & $\begin{array}{c}0.0259^{* * *} \\
{[2.78]}\end{array}$ & $\begin{array}{l}0.0042 \\
{[0.70]}\end{array}$ & $\begin{array}{c}0.0327^{* * *} \\
{[2.95]}\end{array}$ & $\begin{array}{c}0.0285^{* * *} \\
{[3.12]}\end{array}$ & $\begin{array}{c}0.0054 \\
{[0.91]}\end{array}$ & $\begin{array}{c}0.0324^{* * *} \\
{[2.96]}\end{array}$ & $\begin{array}{c}0.0269^{* * *} \\
{[2.94]}\end{array}$ \\
\hline$\beta_{M K T}$ & $\begin{array}{l}0.0009 \\
{[0.19]}\end{array}$ & $\begin{array}{l}-0.0033 \\
{[-0.49]}\end{array}$ & $\begin{array}{c}-0.0042 \\
{[-1.08]}\end{array}$ & $\begin{array}{l}0.0001 \\
{[0.014]}\end{array}$ & $\begin{array}{c}-0.0036 \\
{[-0.55]}\end{array}$ & $\begin{array}{l}-0.0036 \\
{[-0.92]}\end{array}$ & $\begin{array}{l}0.0008 \\
{[0.16]}\end{array}$ & $\begin{array}{c}-0.0028 \\
{[-0.44]}\end{array}$ & $\begin{array}{c}-0.0036 \\
{[-0.97]}\end{array}$ \\
\hline$\beta_{S M B}$ & $\begin{array}{c}0.0134^{* * *} \\
{[3.28]}\end{array}$ & $\begin{array}{c}0.0197^{* *} \\
{[2.14]}\end{array}$ & $\begin{array}{l}0.0063 \\
{[0.84]}\end{array}$ & $\begin{array}{c}0.0132^{* * *} \\
{[3.12]}\end{array}$ & $\begin{array}{c}0.0193^{* *} \\
{[2.08]}\end{array}$ & $\begin{array}{l}0.0061 \\
{[0.84]}\end{array}$ & $\begin{array}{c}0.0118^{* * *} \\
{[2.73]}\end{array}$ & $\begin{array}{c}0.0189^{* *} \\
{[2.07]}\end{array}$ & $\begin{array}{l}0.0071 \\
{[0.98]}\end{array}$ \\
\hline$\beta_{H M L}$ & $\begin{array}{c}0.0096^{* *} \\
{[2.56]}\end{array}$ & $\begin{array}{c}0.0114^{* *} \\
{[1.99]}\end{array}$ & $\begin{array}{l}0.0019 \\
{[0.47]}\end{array}$ & $\begin{array}{c}0.0104^{* * *} \\
{[2.74]}\end{array}$ & $\begin{array}{c}0.0118^{* *} \\
{[2.06]}\end{array}$ & $\begin{array}{l}0.0014 \\
{[0.36]}\end{array}$ & $\begin{array}{c}0.0107^{* * *} \\
{[2.78]}\end{array}$ & $\begin{array}{c}0.0122^{* *} \\
{[2.18]}\end{array}$ & $\begin{array}{l}0.0015 \\
{[0.39]}\end{array}$ \\
\hline Leverage & $\begin{array}{l}0.0020 \\
{[0.20]}\end{array}$ & $\begin{array}{l}0.0286 \\
{[1.56]}\end{array}$ & $\begin{array}{c}0.0266^{* *} \\
{[1.99]}\end{array}$ & $\begin{array}{l}-0.0007 \\
{[-0.074]}\end{array}$ & $\begin{array}{l}0.0291 \\
{[1.58]}\end{array}$ & $\begin{array}{c}0.0298^{* *} \\
{[2.21]}\end{array}$ & $\begin{array}{l}-0.0009 \\
{[-0.089]}\end{array}$ & $\begin{array}{l}0.0265 \\
{[1.45]}\end{array}$ & $\begin{array}{c}0.0274^{* *} \\
{[2.09]}\end{array}$ \\
\hline Growth & $\begin{array}{l}0.0126 \\
{[0.29]}\end{array}$ & $\begin{array}{l}0.0783 \\
{[0.93]}\end{array}$ & $\begin{array}{l}0.0657 \\
{[1.22]}\end{array}$ & $\begin{array}{l}0.0092 \\
{[0.21]}\end{array}$ & $\begin{array}{l}0.0760 \\
{[0.91]}\end{array}$ & $\begin{array}{l}0.0668 \\
{[1.27]}\end{array}$ & $\begin{array}{l}0.0084 \\
{[0.18]}\end{array}$ & $\begin{array}{l}0.0759 \\
{[0.92]}\end{array}$ & $\begin{array}{l}0.0676 \\
{[1.32]}\end{array}$ \\
\hline Coefvar & $\begin{array}{c}0.0154 \\
{[0.91]}\end{array}$ & $\begin{array}{l}0.0312 \\
{[1.12]}\end{array}$ & $\begin{array}{l}0.0158 \\
{[0.62]}\end{array}$ & $\begin{array}{l}0.0153 \\
{[0.82]}\end{array}$ & $\begin{array}{l}0.0279 \\
{[0.92]}\end{array}$ & $\begin{array}{l}0.0126 \\
{[0.53]}\end{array}$ & $\begin{array}{l}0.0151 \\
{[0.86]}\end{array}$ & $\begin{array}{l}0.0293 \\
{[1.01]}\end{array}$ & $\begin{array}{l}0.0142 \\
{[0.57]}\end{array}$ \\
\hline Constant & $\begin{array}{c}0.0891^{* * *} \\
{[8.40]}\end{array}$ & $\begin{array}{c}0.0687^{* * *} \\
{[3.66]}\end{array}$ & $\begin{array}{c}-0.0205 \\
{[-1.66]}\end{array}$ & $\begin{array}{c}0.0434^{* * *} \\
{[4.08]}\end{array}$ & $\begin{array}{l}0.0214 \\
{[1.14]}\end{array}$ & $\begin{array}{c}-0.0220^{*} \\
{[-1.79]}\end{array}$ & $\begin{array}{c}0.0347^{* * *} \\
{[3.19]}\end{array}$ & $\begin{array}{l}0.0132 \\
{[0.72]}\end{array}$ & $\begin{array}{c}-0.0215^{*} \\
{[-1.81]}\end{array}$ \\
\hline Observations & 91 & 91 & 91 & 91 & 91 & 91 & 91 & 91 & 91 \\
\hline AdjR-squared & 0.317 & 0.264 & 0.116 & 0.312 & 0.262 & 0.141 & 0.295 & 0.266 & 0.137 \\
\hline $\begin{array}{l}\text { indicator var } \\
\text { definitions ar } \\
\text { on robust sta }\end{array}$ & $\begin{array}{l}\text { our ma } \\
\text { ents, wh } \\
\text { that equ } \\
\text { a source } \\
\text { d errors }\end{array}$ & $\begin{array}{l}\text { esults or } \\
\text { ere mar } \\
\text { one if } t \\
\text { our dep } \\
\text { eported }\end{array}$ & $\begin{array}{l}\mathrm{m} \text { has } \\
\text { nt var } \\
\text { arentl }\end{array}$ & $\begin{array}{l}\text { n sued } \\
K, R P 3\end{array}$ & $\begin{array}{l}\text { ost of e } \\
\text { exis, con } \\
\text { result } \\
R P 10 \\
\text { h coeffi }\end{array}$ & restat & $\begin{array}{l}\text { Appe } \\
\text { ontrol } \\
\text { upersc }\end{array}$ & $\begin{array}{l}\text {, and lit } \\
\text { o } 2002 \text {. } \\
\text { A. } 2 \text { rep } \\
\text { les. T-st } \\
\text { sterisks }\end{array}$ & $\begin{array}{l}\text { ion. The } \\
\text { tion is ar } \\
\text { detailec } \\
\text { ics basec } \\
* * \text {, and }\end{array}$ \\
\hline
\end{tabular}


Table 5

Robustness test set 1: Clustering

\begin{tabular}{|c|c|c|c|c|c|c|c|c|c|}
\hline Model & (1) & $(2)$ & (3) & (4) & (5) & (6) & (7) & $(8)$ & (9) \\
\hline $\begin{array}{l}\text { Dependent } \\
\text { Variable }\end{array}$ & & K & & & RP3 & & & RP10 & \\
\hline & Before & After & $\begin{array}{c}\text { After } \\
\text { less } \\
\text { Before }\end{array}$ & Before & After & $\begin{array}{c}\text { After } \\
\text { less } \\
\text { Before }\end{array}$ & Before & After & $\begin{array}{c}\text { After } \\
\text { less } \\
\text { Before }\end{array}$ \\
\hline Constant & $\begin{array}{c}0.0891^{* * *} \\
{[7.44]}\end{array}$ & $\begin{array}{c}0.0687^{* * *} \\
{[3.74]}\end{array}$ & $\begin{array}{c}-0.0205^{*} \\
{[-2.04]}\end{array}$ & $\begin{array}{c}0.0434^{* * *} \\
{[4.11]}\end{array}$ & $\begin{array}{l}0.0214 \\
{[1.19]}\end{array}$ & $\begin{array}{c}-0.0220^{* *} \\
{[-2.24]}\end{array}$ & $\begin{array}{c}0.0347^{* * *} \\
{[3.16]}\end{array}$ & $\begin{array}{l}0.0132 \\
{[0.75]}\end{array}$ & $\begin{array}{c}-0.0215^{* *} \\
{[-2.29]}\end{array}$ \\
\hline Litigation & $\begin{array}{l}0.0051 \\
{[0.99]}\end{array}$ & $\begin{array}{c}0.0310^{* * *} \\
{[3.34]}\end{array}$ & $\begin{array}{c}0.0259^{* * *} \\
{[2.91]}\end{array}$ & $\begin{array}{c}0.0042 \\
{[0.78]}\end{array}$ & $\begin{array}{c}0.0327^{* * *} \\
{[3.30]}\end{array}$ & $\begin{array}{c}0.0285^{\star * *} \\
{[3.12]}\end{array}$ & $\begin{array}{c}0.0054 \\
{[0.95]}\end{array}$ & $\begin{array}{c}0.0324^{* * *} \\
{[3.35]}\end{array}$ & $\begin{array}{c}0.0269^{* * *} \\
{[2.83]}\end{array}$ \\
\hline$\beta_{M K T}$ & $\begin{array}{l}0.0009 \\
{[0.19]}\end{array}$ & $\begin{array}{c}-0.0033 \\
{[-0.47]}\end{array}$ & $\begin{array}{c}-0.0042 \\
{[-1.00]}\end{array}$ & $\begin{array}{l}0.0001 \\
{[0.015]}\end{array}$ & $\begin{array}{c}-0.0036 \\
{[-0.51]}\end{array}$ & $\begin{array}{c}-0.0036 \\
{[-0.83]}\end{array}$ & $\begin{array}{l}0.0008 \\
{[0.16]}\end{array}$ & $\begin{array}{c}-0.0028 \\
{[-0.42]}\end{array}$ & $\begin{array}{c}-0.0036 \\
{[-0.88]}\end{array}$ \\
\hline$\beta_{S M B}$ & $\begin{array}{c}0.0134^{* * *} \\
{[3.44]}\end{array}$ & $\begin{array}{c}0.0197^{* *} \\
{[2.13]}\end{array}$ & $\begin{array}{c}0.0063 \\
{[0.81]}\end{array}$ & $\begin{array}{c}0.0132^{* * *} \\
{[3.27]}\end{array}$ & $\begin{array}{c}0.0193^{* *} \\
{[2.08]}\end{array}$ & $\begin{array}{l}0.0061 \\
{[0.83]}\end{array}$ & $\begin{array}{c}0.0118^{* * *} \\
{[2.89]}\end{array}$ & $\begin{array}{c}0.0189^{*} \\
{[2.05]}\end{array}$ & $\begin{array}{c}0.0071 \\
{[0.95]}\end{array}$ \\
\hline$\beta_{H M L}$ & $\begin{array}{c}0.0096^{* * *} \\
{[3.26]}\end{array}$ & $\begin{array}{c}0.0114^{* *} \\
{[2.28]}\end{array}$ & $\begin{array}{l}0.0019 \\
{[0.56]}\end{array}$ & $\begin{array}{c}0.0104^{* * *} \\
{[3.19]}\end{array}$ & $\begin{array}{c}0.0118^{* *} \\
{[2.29]}\end{array}$ & $\begin{array}{l}0.0014 \\
{[0.42]}\end{array}$ & $\begin{array}{c}0.0107^{* * *} \\
{[3.41]}\end{array}$ & $\begin{array}{c}0.0122^{* *} \\
{[2.39]}\end{array}$ & $\begin{array}{l}0.0015 \\
{[0.45]}\end{array}$ \\
\hline leverage & $\begin{array}{l}0.0020 \\
{[0.27]}\end{array}$ & $\begin{array}{c}0.0286^{*} \\
{[1.74]}\end{array}$ & $\begin{array}{c}0.0266^{* *} \\
{[2.60]}\end{array}$ & $\begin{array}{l}-0.0007 \\
{[-0.083]}\end{array}$ & $\begin{array}{l}0.0291 \\
{[1.64]}\end{array}$ & $\begin{array}{c}0.0298^{* *} \\
{[2.63]}\end{array}$ & $\begin{array}{c}-0.0009 \\
{[-0.11]}\end{array}$ & $\begin{array}{l}0.0265 \\
{[1.57]}\end{array}$ & $\begin{array}{c}0.0274^{* *} \\
{[2.60]}\end{array}$ \\
\hline growth & $\begin{array}{l}0.0126 \\
{[0.23]}\end{array}$ & $\begin{array}{l}0.0783 \\
{[0.98]}\end{array}$ & $\begin{array}{l}0.0657 \\
{[1.33]}\end{array}$ & $\begin{array}{l}0.0092 \\
{[0.18]}\end{array}$ & $\begin{array}{l}0.0760 \\
{[0.97]}\end{array}$ & $\begin{array}{l}0.0668 \\
{[1.47]}\end{array}$ & $\begin{array}{l}0.0084 \\
{[0.16]}\end{array}$ & $\begin{array}{l}0.0759 \\
{[0.99]}\end{array}$ & $\begin{array}{c}0.0676 \\
{[1.47]}\end{array}$ \\
\hline coefuar & $\begin{array}{c}0.0154 \\
{[0.84]}\end{array}$ & $\begin{array}{l}0.0312 \\
{[1.12]}\end{array}$ & $\begin{array}{l}0.0158 \\
{[0.59]}\end{array}$ & $\begin{array}{l}0.0153 \\
{[0.78]}\end{array}$ & $\begin{array}{l}0.0279 \\
{[0.93]}\end{array}$ & $\begin{array}{l}0.0126 \\
{[0.51]}\end{array}$ & $\begin{array}{l}0.0151 \\
{[0.80]}\end{array}$ & $\begin{array}{l}0.0293 \\
{[1.02]}\end{array}$ & $\begin{array}{c}0.0142 \\
{[0.54]}\end{array}$ \\
\hline Observations & 91 & 91 & 91 & 91 & 91 & 91 & 91 & 91 & 91 \\
\hline AdjR-squared & 0.317 & 0.264 & 0.116 & 0.312 & 0.262 & 0.141 & 0.295 & 0.266 & 0.137 \\
\hline
\end{tabular}


Table 6

Robustness test set 2: Clustering and Heteroskesdasticity

\begin{tabular}{|c|c|c|c|c|c|c|c|c|c|}
\hline Model & (1) & (2) & (3) & (4) & (5) & (6) & (7) & (8) & (9) \\
\hline \multirow[t]{2}{*}{$\begin{array}{l}\text { Dependent } \\
\text { Variable }\end{array}$} & & $\mathrm{K}$ & & & RP3 & & & RP10 & \\
\hline & Before & After & $\begin{array}{c}\text { After } \\
\text { less } \\
\text { Before }\end{array}$ & Before & After & $\begin{array}{c}\text { After } \\
\text { less } \\
\text { Before }\end{array}$ & Before & After & $\begin{array}{c}\text { After } \\
\text { less } \\
\text { Before }\end{array}$ \\
\hline Constant & $\begin{array}{c}0.0891^{* * *} \\
{[7.44]}\end{array}$ & $\begin{array}{c}0.0687^{* * *} \\
{[3.74]}\end{array}$ & $\begin{array}{c}-0.0205^{*} \\
{[-2.04]}\end{array}$ & $\begin{array}{c}0.0434^{* * *} \\
{[4.11]}\end{array}$ & $\begin{array}{l}0.0214 \\
{[1.19]}\end{array}$ & $\begin{array}{c}-0.0220^{* *} \\
{[-2.24]}\end{array}$ & $\begin{array}{c}0.0347^{* * *} \\
{[3.16]}\end{array}$ & $\begin{array}{c}0.0132 \\
{[0.75]}\end{array}$ & $\begin{array}{c}-0.0215^{* *} \\
{[-2.29]}\end{array}$ \\
\hline Litigation & $\begin{array}{l}0.0051 \\
{[0.99]}\end{array}$ & $\begin{array}{c}0.0310^{* * *} \\
{[3.34]}\end{array}$ & $\begin{array}{c}0.0259 * * * \\
{[2.91]}\end{array}$ & $\begin{array}{l}0.0042 \\
{[0.78]}\end{array}$ & $\begin{array}{c}0.0327^{* * *} \\
{[3.30]}\end{array}$ & $\begin{array}{c}0.0285^{* * *} \\
{[3.12]}\end{array}$ & $\begin{array}{l}0.0054 \\
{[0.95]}\end{array}$ & $\begin{array}{c}0.0324^{* * *} \\
{[3.35]}\end{array}$ & $\begin{array}{c}0.0269^{* * *} \\
{[2.83]}\end{array}$ \\
\hline$\beta_{M K T}$ & $\begin{array}{l}0.0009 \\
{[0.19]}\end{array}$ & $\begin{array}{c}-0.0033 \\
{[-0.47]}\end{array}$ & $\begin{array}{c}-0.0042 \\
{[-1.00]}\end{array}$ & $\begin{array}{l}0.0001 \\
{[0.015]}\end{array}$ & $\begin{array}{l}-0.0036 \\
{[-0.51]}\end{array}$ & $\begin{array}{c}-0.0036 \\
{[-0.83]}\end{array}$ & $\begin{array}{l}0.0008 \\
{[0.16]}\end{array}$ & $\begin{array}{c}-0.0028 \\
{[-0.42]}\end{array}$ & $\begin{array}{c}-0.0036 \\
{[-0.88]}\end{array}$ \\
\hline$\beta_{S M B}$ & $\begin{array}{c}0.0134^{* * *} \\
{[3.44]}\end{array}$ & $\begin{array}{c}0.0197^{* *} \\
{[2.13]}\end{array}$ & $\begin{array}{c}0.0063 \\
{[0.81]}\end{array}$ & $\begin{array}{c}0.0132^{* * *} \\
{[3.27]}\end{array}$ & $\begin{array}{c}0.0193^{* *} \\
{[2.08]}\end{array}$ & $\begin{array}{l}0.0061 \\
{[0.83]}\end{array}$ & $\begin{array}{c}0.0118^{* * *} \\
{[2.89]}\end{array}$ & $\begin{array}{c}0.0189^{*} \\
{[2.05]}\end{array}$ & $\begin{array}{c}0.0071 \\
{[0.95]}\end{array}$ \\
\hline$\beta_{H M L}$ & $\begin{array}{c}0.0096^{* * *} \\
{[3.26]}\end{array}$ & $\begin{array}{c}0.0114^{* *} \\
{[2.28]}\end{array}$ & $\begin{array}{l}0.0019 \\
{[0.56]}\end{array}$ & $\begin{array}{c}0.0104^{* * *} \\
{[3.19]}\end{array}$ & $\begin{array}{c}0.0118^{* *} \\
{[2.29]}\end{array}$ & $\begin{array}{l}0.0014 \\
{[0.42]}\end{array}$ & $\begin{array}{c}0.0107^{* * *} \\
{[3.41]}\end{array}$ & $\begin{array}{c}0.0122^{* *} \\
{[2.39]}\end{array}$ & $\begin{array}{l}0.0015 \\
{[0.45]}\end{array}$ \\
\hline leverage & $\begin{array}{l}0.0020 \\
{[0.27]}\end{array}$ & $\begin{array}{c}0.0286^{*} \\
{[1.74]}\end{array}$ & $\begin{array}{c}0.0266^{* *} \\
{[2.60]}\end{array}$ & $\begin{array}{l}-0.0007 \\
{[-0.083]}\end{array}$ & $\begin{array}{l}0.0291 \\
{[1.64]}\end{array}$ & $\begin{array}{c}0.0298^{* *} \\
{[2.63]}\end{array}$ & $\begin{array}{l}-0.0009 \\
{[-0.11]}\end{array}$ & $\begin{array}{l}0.0265 \\
{[1.57]}\end{array}$ & $\begin{array}{c}0.0274^{* *} \\
{[2.60]}\end{array}$ \\
\hline growth & $\begin{array}{l}0.0126 \\
{[0.23]}\end{array}$ & $\begin{array}{l}0.0783 \\
{[0.98]}\end{array}$ & $\begin{array}{l}0.0657 \\
{[1.33]}\end{array}$ & $\begin{array}{l}0.0092 \\
{[0.18]}\end{array}$ & $\begin{array}{l}0.0760 \\
{[0.97]}\end{array}$ & $\begin{array}{l}0.0668 \\
{[1.47]}\end{array}$ & $\begin{array}{l}0.0084 \\
{[0.16]}\end{array}$ & $\begin{array}{l}0.0759 \\
{[0.99]}\end{array}$ & $\begin{array}{c}0.0676 \\
{[1.47]}\end{array}$ \\
\hline coefuar & $\begin{array}{l}0.0154 \\
{[0.84]}\end{array}$ & $\begin{array}{l}0.0312 \\
{[1.12]}\end{array}$ & $\begin{array}{l}0.0158 \\
{[0.59]}\end{array}$ & $\begin{array}{l}0.0153 \\
{[0.78]}\end{array}$ & $\begin{array}{l}0.0279 \\
{[0.93]}\end{array}$ & $\begin{array}{l}0.0126 \\
{[0.51]}\end{array}$ & $\begin{array}{l}0.0151 \\
{[0.80]}\end{array}$ & $\begin{array}{l}0.0293 \\
{[1.02]}\end{array}$ & $\begin{array}{l}0.0142 \\
{[0.54]}\end{array}$ \\
\hline Observations & 91 & 91 & 91 & 91 & 91 & 91 & 91 & 91 & 91 \\
\hline AdjR-squared & 0.317 & 0.264 & 0.116 & 0.312 & 0.262 & 0.141 & 0.295 & 0.266 & 0.137 \\
\hline $\begin{array}{l}\text { This table pres } \\
\text { litigation. The } \\
\text { Litigation is an } \\
\text { detailed defini } \\
\text { based on robus } \\
\text { coefficient esti } \\
\text { tailed tests are }\end{array}$ & $\begin{array}{l}\text { obustness } \\
\text { le of rest } \\
\text { ator vari } \\
\text { and data } \\
\text { dard erro } \\
\text { Superscri } \\
\text { only whe }\end{array}$ & $\begin{array}{l}\text { esults pr } \\
\text { nents, wl } \\
\text { that equ } \\
\text { rces for o } \\
\text { djusted } \mathrm{f} \\
\text { isterisks } \\
\text { edictions }\end{array}$ & $\begin{array}{l}\text { ted in } \mathrm{T} \\
\text { were } \mathrm{m} \\
\text { one if } \mathrm{t} \\
\text { lepende } \\
\text { eteroske } \\
{ }^{*} \text {, and } \\
\text { made. }\end{array}$ & $\begin{array}{l}3 \text { on the } \\
\text { lly colle } \\
\text { m has } \\
\text { riables } \\
\text { city and } \\
\text { ote stati }\end{array}$ & $\begin{array}{l}\text { tionship } \\
\text { I from Le } \\
\text { sued a } \\
P 3 \text {, and } \\
\text { stered by } \\
1 \text { signific }\end{array}$ & $\begin{array}{l}\text { veen cos } \\
\text { Nexis, } \\
\text { esult of } \\
\text { and all } \\
\text { ustry ar } \\
\text { e at the }\end{array}$ & $\begin{array}{l}\text { equity, } \mathrm{f} \\
\text { sts of } 91 \\
\text { estateme } \\
\text { and cor } \\
\text { ported in } \\
5 \%, 10 \%\end{array}$ & $\begin{array}{l}\text { icial resta } \\
\text { nts from } \\
\text { Appendi } \\
\text { variable } \\
\text { entheses } \\
\text { els, respe }\end{array}$ & $\begin{array}{l}\text { ments, and } \\
997 \text { to } 2002 \\
\text { A.2 reports } \\
\text { T-statistics } \\
\text { neath each } \\
\text { ively; one- }\end{array}$ \\
\hline
\end{tabular}




\section{Table 7}

Robustness test set 3: Different Proxies for Risk, Size and Valuation

\begin{tabular}{|c|c|c|c|c|c|c|c|c|c|}
\hline Model & (1) & $(2)$ & (3) & $(4)$ & (5) & (6) & (7) & (8) & (9) \\
\hline \multirow{2}{*}{ Dependent Variable } & & K & & \multicolumn{3}{|c|}{ RP3 } & \multicolumn{3}{|c|}{ RP10 } \\
\hline & Before & After & $\begin{array}{l}\text { After less } \\
\text { Before }\end{array}$ & Before & After & $\begin{array}{l}\text { After less } \\
\text { Before }\end{array}$ & Before & After & $\begin{array}{c}\text { After less } \\
\text { Before }\end{array}$ \\
\hline \multirow{2}{*}{ Constant } & $0.1130^{* * *}$ & $0.1064^{* * *}$ & -0.0066 & $0.0677^{* * *}$ & $0.0583^{* *}$ & -0.0094 & $0.0580^{* * *}$ & $0.0511^{* *}$ & -0.0070 \\
\hline & {$[10.1]$} & {$[5.08]$} & {$[-0.56]$} & [5.95] & {$[2.79]$} & {$[-0.85]$} & [5.19] & [2.49] & {$[-0.63]$} \\
\hline \multirow[t]{2}{*}{ Litigation } & 0.0064 & $0.0340^{* * *}$ & $0.0276^{* * *}$ & 0.0054 & $0.0355^{* * *}$ & $0.0301^{* * *}$ & 0.0061 & $0.0349^{* * *}$ & $0.0288^{* * *}$ \\
\hline & [1.07] & {$[2.88]$} & {$[2.58]$} & {$[0.86]$} & {$[2.84]$} & {$[2.77]$} & {$[0.95]$} & {$[2.85]$} & [2.59] \\
\hline \multirow[t]{2}{*}{ Beta } & 0.0057 & 0.0032 & -0.0025 & 0.0054 & 0.0030 & -0.0024 & 0.0052 & 0.0033 & -0.0018 \\
\hline & {$[1.40]$} & {$[0.50]$} & {$[-0.67]$} & [1.35] & {$[0.49]$} & {$[-0.66]$} & [1.29] & {$[0.54]$} & {$[-0.50]$} \\
\hline \multirow[t]{2}{*}{ AnalystCoverage } & $-0.0102^{* * *}$ & $-0.0180^{* * *}$ & $-0.0079 * * *$ & $-0.0106^{* * *}$ & $-0.0177^{* * *}$ & $-0.0070^{* * *}$ & $-0.0098^{* * *}$ & $-0.0180^{* * *}$ & $-0.0082^{* * *}$ \\
\hline & {$[-2.97]$} & {$[-3.82]$} & {$[-3.23]$} & {$[-3.17]$} & {$[-4.03]$} & {$[-3.22]$} & {$[-3.10]$} & {$[-4.24]$} & {$[-3.54]$} \\
\hline \multirow[t]{2}{*}{ market_book } & $-0.0031^{* * *}$ & $-0.0034^{* * *}$ & -0.0003 & $-0.0031^{* * *}$ & $-0.0033^{* * *}$ & -0.0002 & $-0.0031^{* * *}$ & $-0.0034^{* * *}$ & -0.0003 \\
\hline & {$[-4.80]$} & {$[-3.44]$} & {$[-0.56]$} & {$[-4.76]$} & {$[-3.29]$} & {$[-0.40]$} & {$[-4.69]$} & {$[-3.50]$} & {$[-0.49]$} \\
\hline \multirow[t]{2}{*}{ leverage } & 0.0137 & 0.0374 & $0.0238^{* *}$ & 0.0116 & 0.0385 & $0.0269^{* *}$ & 0.0127 & 0.0369 & $0.0242^{* *}$ \\
\hline & [1.00] & [1.64] & [2.25] & {$[0.75]$} & [1.60] & [2.52] & {$[0.81]$} & [1.57] & {$[2.38]$} \\
\hline \multirow[t]{2}{*}{ growth } & 0.0372 & 0.1043 & 0.0671 & 0.0301 & 0.0990 & 0.0688 & 0.0304 & 0.0987 & 0.0684 \\
\hline & {$[0.65]$} & [1.01] & {$[1.24]$} & {$[0.52]$} & [0.97] & [1.37] & {$[0.54]$} & [0.99] & [1.34] \\
\hline \multirow[t]{2}{*}{ coefvar } & 0.0114 & 0.0306 & 0.0192 & 0.0114 & 0.0274 & 0.0161 & 0.0103 & 0.0283 & 0.0180 \\
\hline & {$[0.55]$} & [1.22] & {$[0.77]$} & {$[0.51]$} & [0.98] & {$[0.68]$} & {$[0.47]$} & [1.08] & {$[0.74]$} \\
\hline Observations & 91 & 91 & 91 & 91 & 91 & 91 & 91 & 91 & 91 \\
\hline AdjR-squared & 0.339 & 0.280 & 0.123 & 0.331 & 0.270 & 0.145 & 0.323 & 0.278 & 0.141 \\
\hline
\end{tabular}

This table presents robustness of results presented in Table 3 on the relationship between cost of equity, financial restatements, and litigation. The sample of restatements, which were manually collected from Lexis-Nexis, consists of 91 events from 1997 to 2002 Litigation is an indicator variable that equals one if the firm has been sued as a result of a restatement. Appendix A.2 reports detailed definitions and data sources for our dependent variables $K, R P 3$, and $R P 10$ and all test and control variables. Among the additional variables, beta is the beta from the single factor CAPM, AnalystCoverage is the number of analysts following a firm, market_book is market value of equity divided by book value of equity. T-statistics based on robust standard errors adjusted for heteroskedasticity and clustered by industry are reported in parentheses beneath each coefficient estimate. Superscript asterisks ***, **, and * denote statistical significance at the 1\%,5\%,10\% levels, respectively; one-tailed tests are used only when predictions are made. 
Table 8

Robustness test set 4: Hribar and Jenkins (2004) Specifications

\begin{tabular}{|c|c|c|c|c|c|c|c|c|c|}
\hline Model & (1) & (2) & (3) & (4) & (5) & (6) & $(7)$ & (8) & (9) \\
\hline \multirow{2}{*}{$\begin{array}{l}\text { Dependent } \\
\text { Variable }\end{array}$} & \multicolumn{3}{|c|}{ K } & \multicolumn{3}{|c|}{ RP3 } & \multicolumn{3}{|c|}{ RP10 } \\
\hline & Before & After & $\begin{array}{l}\text { After less } \\
\text { Before }\end{array}$ & Before & After & $\begin{array}{l}\text { After less } \\
\text { Before }\end{array}$ & Before & After & $\begin{array}{l}\text { After less } \\
\text { Before }\end{array}$ \\
\hline \multirow[t]{2}{*}{ Constant } & $0.1347^{* * *}$ & $0.1110^{* *}$ & -0.0237 & $0.0834^{* * *}$ & 0.0586 & -0.0248 & $0.0699 * * *$ & 0.0467 & -0.0232 \\
\hline & [4.29] & [2.59] & {$[-0.74]$} & [3.29] & [1.36] & {$[-0.79]$} & [2.75] & [1.09] & {$[-0.74]$} \\
\hline \multirow[t]{2}{*}{ Litigation } & 0.0082 & $0.0325^{* *}$ & $0.0243^{* * *}$ & 0.0062 & $0.0336^{* * *}$ & $0.0274^{* * *}$ & 0.0067 & $0.0330^{* * *}$ & $0.0263^{* * *}$ \\
\hline & [1.26] & [2.63] & [2.66] & {$[0.84]$} & [2.70] & [3.04] & [0.92] & [2.67] & [2.91] \\
\hline \multirow[t]{2}{*}{ core } & -0.0002 & -0.0050 & -0.0048 & 0.0011 & -0.0046 & -0.0056 & 0.0013 & -0.0052 & -0.0065 \\
\hline & {$[-0.024]$} & {$[-0.44]$} & {$[-0.57]$} & [0.16] & {$[-0.40]$} & {$[-0.68]$} & {$[0.20]$} & {$[-0.46]$} & {$[-0.78]$} \\
\hline \multirow[t]{2}{*}{ company } & 0.0068 & 0.0228 & 0.0160 & 0.0044 & 0.0193 & 0.0149 & 0.0076 & 0.0233 & 0.0157 \\
\hline & {$[0.71]$} & [1.13] & [1.07] & [0.37] & [0.95] & [1.01] & {$[0.64]$} & [1.15] & [1.06] \\
\hline \multirow[t]{2}{*}{ auditor } & -0.0088 & 0.0083 & 0.0171 & -0.0116 & 0.0022 & 0.0139 & -0.0095 & 0.0048 & 0.0143 \\
\hline & {$[-0.53]$} & [0.29] & [0.82] & {$[-0.70]$} & [0.079] & [0.67] & {$[-0.57]$} & [0.17] & [0.69] \\
\hline \multirow[t]{2}{*}{$\mathrm{sec}$} & -0.0010 & -0.0055 & -0.0045 & -0.0073 & -0.0105 & -0.0032 & -0.0030 & -0.0058 & -0.0028 \\
\hline & {$[-0.10]$} & {$[-0.28]$} & {$[-0.31]$} & {$[-0.63]$} & {$[-0.53]$} & {$[-0.22]$} & {$[-0.26]$} & {$[-0.30]$} & {$[-0.19]$} \\
\hline \multirow[t]{2}{*}{ size } & $-0.0043^{*}$ & -0.0032 & 0.0011 & -0.0031 & -0.0023 & 0.0009 & -0.0030 & -0.0022 & 0.0008 \\
\hline & {$[-1.86]$} & {$[-0.77]$} & [0.35] & {$[-1.28]$} & {$[-0.54]$} & [0.29] & {$[-1.23]$} & {$[-0.53]$} & [0.27] \\
\hline \multirow[t]{2}{*}{ leverage } & 0.0167 & $0.0366^{*}$ & 0.0199 & 0.0127 & $0.0367^{*}$ & 0.0241 & 0.0138 & $0.0356^{*}$ & 0.0217 \\
\hline & [1.08] & [1.79] & [1.32] & [1.05] & [1.79] & [1.61] & [1.14] & [1.74] & [1.45] \\
\hline \multirow[t]{2}{*}{ growth } & -0.0340 & 0.0174 & 0.0514 & -0.0334 & 0.0237 & 0.0571 & -0.0327 & 0.0251 & 0.0579 \\
\hline & {$[-0.50]$} & {$[0.25]$} & [1.00] & {$[-0.81]$} & {$[0.34]$} & [1.13] & {$[-0.79]$} & {$[0.36]$} & {$[1.14]$} \\
\hline Observations & 91 & 91 & 91 & 91 & 91 & 91 & 91 & 91 & 91 \\
\hline Adj R-squared & 0.018 & 0.133 & 0.131 & 0.008 & 0.138 & 0.151 & 0.007 & 0.134 & 0.142 \\
\hline
\end{tabular}

This table presents robustness of results presented in Table 3 on the relationship between cost of equity, financial restatements, and litigation. The sample of restatements, which were manually collected from Lexis-Nexis , consists of 91 events from 1997 to 2002. Litigation is an indicator variable that equals one if the firm has been sued as a result of a restatement. Appendix A.2 reports detailed definitions and data sources for our dependent variables K, RP3, and RP10. Core is one if the restatement relates to core earnings and zero otherwise; company is one if the restatement initiated by company and zero otherwise; auditor is one if the restatement initiated by auditor and zero otherwise; sec is one if the restatement initiated by SEC and zero otherwise; size is log of total sales, leverage is total debt divided total market value equity plus total debt, growth is the long-term growth in earnings forecasts. T-statistics based on robust standard errors and adjusted for heteroskesdasticity are reported in parentheses beneath each coefficient estimate. Superscript asterisks ${ }^{* * *}$, **, and * denote statistical significance at the $1 \%, 5 \%, 10 \%$ levels, respectively; one-tailed tests are used only when predictions are made. 
Table 9

Robustness test set 5: Model Cost of Equity

\begin{tabular}{|c|c|c|c|c|c|c|c|c|c|c|c|c|}
\hline Model & $(1)$ & $(2)$ & (3) & $(4)$ & (5) & (6) & (7) & $(8)$ & (9) & $(10)$ & $(11)$ & $(12)$ \\
\hline \multirow[t]{2}{*}{ Dependent_Var } & & Koj & & & Kes & & & Kct & & & Kgls & \\
\hline & Before & After & $\begin{array}{l}\text { After less } \\
\text { Before }\end{array}$ & Before & After & $\begin{array}{l}\text { After less } \\
\text { Before }\end{array}$ & Before & After & $\begin{array}{l}\text { After less } \\
\text { Before }\end{array}$ & Before & After & $\begin{array}{c}\text { After less } \\
\text { Before }\end{array}$ \\
\hline \multirow{2}{*}{ Constant } & $0.0963^{* * *}$ & $0.0795^{* * *}$ & -0.0169 & $0.0931^{* * *}$ & $0.0766^{* * *}$ & -0.0166 & $0.0752^{* * *}$ & $0.0413^{*}$ & $-0.0338^{* *}$ & $0.0839^{* * *}$ & $0.0684^{* * *}$ & $-0.0154^{* *}$ \\
\hline & [9.34] & [4.49] & {$[-1.25]$} & [6.58] & [3.27] & {$[-0.88]$} & [6.44] & [1.80] & {$[-2.23]$} & [9.82] & [5.61] & {$[-2.52]$} \\
\hline \multirow[t]{2}{*}{ Litigation } & 0.0031 & $0.0290^{* * *}$ & $0.0259^{* * *}$ & -0.0018 & $0.0305^{* *}$ & $0.0323^{* * *}$ & $0.0140^{* *}$ & $0.0438^{* * *}$ & $0.0298^{* *}$ & 0.0038 & $0.0202^{* * *}$ & $0.0165^{* * *}$ \\
\hline & [0.47] & [3.16] & [3.03] & {$[-0.21]$} & [2.37] & [2.60] & [2.03] & [2.48] & [1.97] & [0.70] & [2.56] & [3.25] \\
\hline \multirow{2}{*}{$\beta_{M K T}$} & 0.0002 & -0.0046 & -0.0048 & 0.0006 & -0.0058 & -0.0064 & 0.0018 & -0.0021 & -0.0038 & -0.0006 & -0.0014 & -0.0008 \\
\hline & [0.053] & {$[-0.72]$} & {$[-1.19]$} & {$[0.10]$} & {$[-0.66]$} & {$[-1.05]$} & [0.32] & {$[-0.25]$} & {$[-0.70]$} & {$[-0.14]$} & {$[-0.27]$} & {$[-0.32]$} \\
\hline \multirow{2}{*}{$\beta_{S M B}$} & $0.0129^{* * *}$ & $0.0158^{* *}$ & 0.0029 & $0.0162^{* * *}$ & $0.0181^{*}$ & 0.0019 & $0.0135^{* * *}$ & $0.0307^{*}$ & 0.0172 & $0.0112^{* * *}$ & $0.0145^{\star * *}$ & 0.0033 \\
\hline & [3.17] & [2.14] & {$[0.48]$} & [2.98] & [1.89] & {$[0.23]$} & [2.84] & [1.91] & {$[1.25]$} & [3.68] & [2.67] & {$[0.90]$} \\
\hline \multirow{2}{*}{$\beta_{H M L}$} & $0.0087^{* *}$ & $0.0115^{* *}$ & 0.0029 & $0.0115^{* *}$ & $0.0151^{*}$ & 0.0036 & $0.0105^{* *}$ & 0.0107 & 0.0001 & $0.0086^{* * *}$ & $0.0092^{* *}$ & 0.0006 \\
\hline & [2.29] & [2.07] & {$[0.70]$} & {$[2.31]$} & [1.94] & {$[0.59]$} & [2.42] & {$[1.47]$} & {$[0.023]$} & [2.79] & [2.33] & {$[0.28]$} \\
\hline \multirow[t]{2}{*}{ leverage } & 0.0097 & $0.0325^{*}$ & 0.0228 & 0.0120 & 0.0368 & 0.0248 & 0.0052 & $0.0489^{* *}$ & $0.0437^{* *}$ & -0.0105 & 0.0042 & $0.0147^{* *}$ \\
\hline & {$[0.93]$} & [1.84] & {$[1.61]$} & {$[0.83]$} & {$[1.48]$} & {$[1.17]$} & {$[0.45]$} & [2.10] & {$[2.54]$} & {$[-1.25]$} & {$[0.34]$} & [2.01] \\
\hline \multirow{2}{*}{ growth } & 0.0373 & 0.1023 & 0.0650 & 0.0275 & 0.1056 & 0.0782 & 0.0581 & 0.1302 & 0.0721 & -0.0356 & 0.0103 & $0.0459^{* *}$ \\
\hline & {$[0.92]$} & {$[1.37]$} & {$[1.27]$} & {$[0.52]$} & {$[1.10]$} & {$[1.22]$} & {$[1.16]$} & {$[1.12]$} & {$[0.87]$} & {$[-1.15]$} & {$[0.23]$} & [2.04] \\
\hline \multirow[t]{2}{*}{ coefvar } & 0.0239 & 0.0497 & 0.0258 & $0.0560^{*}$ & $0.1029^{* *}$ & 0.0469 & -0.0178 & -0.0334 & -0.0156 & -0.0105 & -0.0038 & 0.0066 \\
\hline & {$[1.17]$} & {$[1.66]$} & {$[0.91]$} & [1.75] & [2.28] & {$[1.01]$} & {$[-1.44]$} & {$[-1.31]$} & {$[-0.67]$} & {$[-0.82]$} & {$[-0.20]$} & {$[0.53]$} \\
\hline Observations & 91 & 91 & 91 & 91 & 91 & 91 & 91 & 91 & 91 & 91 & 91 & 91 \\
\hline Adj R-squared & 0.279 & 0.305 & 0.122 & 0.309 & 0.270 & 0.076 & 0.307 & 0.211 & 0.080 & 0.277 & 0.231 & 0.166 \\
\hline
\end{tabular}

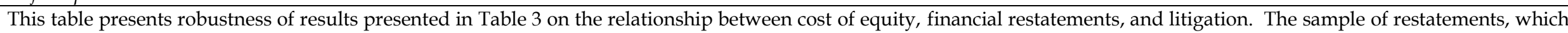

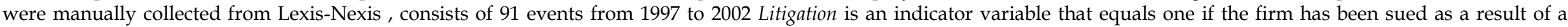

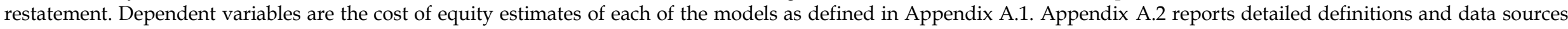

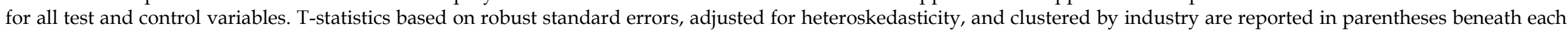

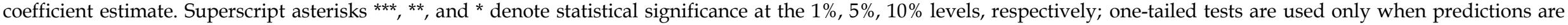
made. 